\title{
Removal of pathogenic bacteria from sewage-treated effluent and biosolids for agricultural purposes
}

\author{
A. A. Al-Gheethi ${ }^{1}$ (1) - A. N. Efaq ${ }^{5}$. J. D. Bala ${ }^{3} \cdot$ I Norli $^{2}$ - M. O. Abdel-Monem ${ }^{4}$ - M. O. Ab. Kadir ${ }^{2}$
}

Received: 10 July 2014 / Accepted: 4 April 2018 / Published online: 4 May 2018

(c) The Author(s) 2018

\begin{abstract}
The reuse of treated sewage for irrigation is considered as an important alternative water source in the new water management strategy of the countries that face a severe deficiency of water resources such as the Middle East countries. The organic material and fertilizing elements contained in biosolids are essential for maintaining soil fertility. However, both treated sewage and biosolids contain a large diversity of pathogens that would be transmitted to the environment and infect human directly or indirectly. Therefore, those pathogens should be reduced from the treated sewage and biosolids before the reuse in the agriculture. This paper reviews the considerations for reuse of treated sewage and biosolids in agriculture and further treatments used for reduction of pathogenic bacteria. The treatment methods used for the reduction of pathogens in these wastes have reviewed. It appeared that the main concern associated with the reduction of pathogenic bacteria lies in their ability to regrow in the treated sewage and biosolids. Therefore, the effective treatment method is that it has the potential to destruct pathogens cells and remove the nutrients to prevent the regrowth or recontamination from the surrounded environment. The removal of nutrients might be applicable in the sewage but not in the biosolids due to high nutrient contents. However, the reduction of health risk in the biosolids might be carried out by regulating the biosolid utilization and selecting the plant species grown in the fertilized soil with biosolids.
\end{abstract}

Keywords Treated sewage $\cdot$ Biosolids $\cdot$ Pathogenic bacteria $\cdot$ Reuse $\cdot$ Treatment technology $\cdot$ Pathogen growth potential

A. A. Al-Gheethi

adel@uthm.edu.my

1 Department of Water and Environmental Engineering, Faculty of Civil and Environmental Engineering, Micro-pollution Research Centre (MPRC), Universiti Tun Hussein Onn Malaysia, Parit Raja, 86400 Batu Pahat, Johor, Malaysia

2 Environmental Technology Division, School of Industrial Technology, Universiti Sains Malaysia (USM), 11800 Penang, Malaysia

3 Department of Microbiology, School of Life Sciences, Federal University of Technology, P.M.B 65, Minna, Niger State, Nigeria

4 Botany Department, Faculty of Science, Benha University, Banha, Egypt

5 Department of Applied Microbiology, Faculty of Applied Sciences, Taiz University, Taiz, Yemen

\section{Introduction}

Sewage effluent is defined as treated or untreated wastewater generated from a treatment plant (US EPA 2009). The treated sewage is classified based on its origin in domestic sewage, hospital sewage and industrial wastewaters. Domestic sewage is a complex mixture containing water together with organic and inorganic constituents and large numbers of pathogenic bacteria as well as viruses and parasites (US EPA 2003). Hospital sewage is that coming from the hospitals and medical centres and includes sewage and wastewater resulting from the cleaning of laboratories and other facilities. Antibiotics, disinfectants and antibiotic-resistant bacteria are the major constituents in these wastes (due to their major use in hospital practice) (Pauwels and Verstraete 2006; Jury et al. 2010).

Industrial wastewaters are unwanted wastewater from the industrial operation such as chemical, electrochemical, electronic, petro-chemical and food-processing industries (US EPA 2009). These wastewaters are associated with high concentrations of dissolved metal salts (heavy metals) and 
may include some domestic sewage, but the domestic sewage is not the main component (Rao et al. 2012; Yachigo and Sato 2013).

The sewage sludge is the solid, semisolid or liquid residue generated during the sewage treatment processes (US EPA 1993). The term sewage sludge has been replaced recently by the term biosolids. Biosolids represent sewage sludge that has been treated by advanced processes which included aerobic and anaerobic, heat or lime treatment and has met standards required for beneficial use. The particular characteristics of the biosolids vary depending on their origin (human, vegetable or animal) and the treatment process they have gone through (physical, chemical or biological, anaerobic or aerobic treatment, alkaline treatment by lime, etc.). The organic and inorganic contents of biosolids are essential for soil and plants (N'Dayegamiye et al. 2002 and Nowak 2007).

Solids recovered from industrial processes are also called sludge and the term is often associated with potentially hazardous industrial wastes. Industrial sludge may have little or no agronomic value. Hence, it is important to distinguish those solids produced from sewage that have value as a fertilizer or soil amendment (John 2005).

Treated sewage and biosolids contain high concentrations of nutrients, which improve plant growth and soil properties. However, it has pathogenic microorganisms such as bacteria, protozoa, viruses and parasites that can cause several diseases. Land application of treated sewage and biosolids creates a potential for human exposure to these organisms through direct and indirect contact. Therefore, to protect public health from these organisms, many countries have regulated the use and disposal of treated sewage and biosolids (Al-Gheethi et al. 2015).

In the field of biosolids, there are some technologies that have been developed which aimed to produce safe biosolids that had to be used as fertilizer in agriculture. The developments in this area are less than that in the field of sewage effluent treatment. However, some of the advanced technologies including temperature-phased anaerobic digestion and autothermal aerobic digestion processes have emerged (Wen et al. 2009; Jin et al. 2013). Further, the membrane filtration, ionised irradiation and oxidation processes by chemical disinfectants exhibited high treatment efficacy in the improvement of the quality of biosolids (Dutta et al. 1999; Aksu and Tunc 2005; Gomez et al. 2006; Dungeni et al. 2010; Tripathi et al. 2011).

In the present review, the main pathogenic bacteria that exist in treated sewage and biosolids are discussed. The treatment processes most common in the reduction of pathogenic bacteria in treated sewage and biosolids are revealed. Treatment processes that would produce treated sewage and biosolids of higher quality for reuse in agriculture, as well as their applicability in Middle East countries and other developing countries, are highlighted.

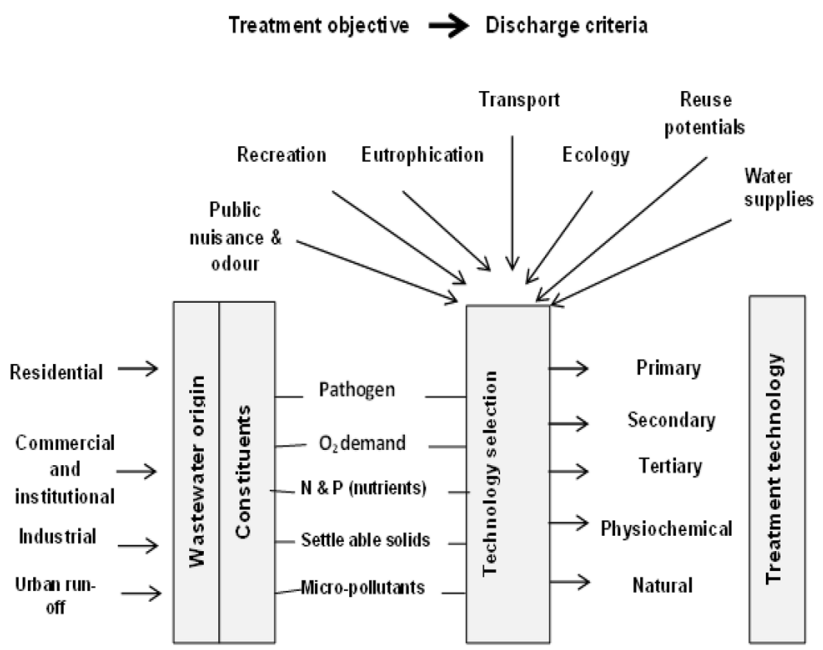

Fig. 1 Treatment technology selection in relation to the origin of the sewage (Veenstra et al. 1997)

\section{Importance of sewage treatment}

Human waste has increased tremendously with concomitant rapid growth of communities and cities. Large numbers of pathogenic microorganisms such as bacteria, viruses and protozoa parasites have originated from the sewage (US EPA 2003). Poor sanitation and contamination of drinking water have led to the death of more than 2000 children every day under the age five worldwide (UNICEF 2013). Hence, there is a need for sewage management to advert the magnitude of ecological degradation due to untreated sewage in the environment. Therefore, the selection of an appropriate technology for the treatment and disposal of treated sewage requires an analysis of the effects that the effluents would have on both agricultural and the environment (Zhou and Smith 2002).

Biosolid production has been estimated to be $20 \times 10^{9}$ tons annually worldwide (Markosyan et al. 2002). Hence, the management of sewage sludge has been a vital environmental issue worldwide. However, in the Middle East countries, adoption of a practical, economic and acceptable approach in managing and disposing sewage sludge is not applicable. The present practice is either to reuse for agricultural purpose or direct disposal in sea (UN 2003).

Sewage treatment system is a multistage process to remove organic matter, heavy metals, causative agents of diseases and other pollutants before its disposal or reuse for the agriculture (Al-Rekabi et al. 2007; Wani et al. 2013). The degree of treatment range from basic process such as individual septic tanks (ISTs), oxidation ponds, stabilization ponds, primary and secondary processes for heavily polluted waste to polishing process (advanced or tertiary process) for removing the trace concentrations, 
which remain after the main treatment (Gupta et al. 2000; Heritage et al. 2003). The final selection of sewage treatment technology depends on the source of sewage and its applicability (Fig. 1). The common sewage treatment processes can be presented as follows.

\section{Disposal and reuse of treated sewage and biosolids}

In the planning and designing of sewage treatment facilities, the disposal of treated sewage and biosolids is an integral part of this structure. After the treatment, both treated sewage and biosolids are discharged into the environment or reused for agricultural purposes (UN 2003). In Middle East countries, the common practices of treated sewage depend on the country's economic structure. The discharge of treated sewage into the natural water is common in the coastal cities which takes advantage of the self-purification capacity of water bodies for the further treatment of treated sewage (UN 2003; Fine et al. 2006). However, these practices are becoming unacceptable due to increase of the smells generated and the volume of the wastes involved as well as risks to health (Heritage et al. 2003). The extreme quantities of organic compounds may cause a reduction of the dissolved oxygen resources of the natural waters and rapid bacterial growth. The changes in heavy metal concentrations and $\mathrm{pH}$ values are harmful to organisms in these water bodies (UN 2003).

Recently, many water sources (e.g. seas, rivers, oceans and surface water) started to represent health risks for humans due to the disposal of treated sewage contaminated with pathogenic bacteria (Wen et al. 2009; Garcia-Armisen et al. 2011). A wide variety of microbial pathogens that may pose a risk to human health are known to be abundant in the treated sewage and considered the major source of faecal contamination in aquatic ecosystems (Scott et al. 2003; Tyagi et al. 2006).

Transmission of infectious pathogenic organisms into rivers and water bodies from sewage effluent discharge increases the contamination by pathogenic bacteria such as Salmonella spp., Shigella spp., P. aeruginosa, S. aureus, E. coli, $V$. cholerae, $Y$. enterocolitica and $C$. jejuni (US EPA 1988; WHO 1993; Santhiya et al. 2011). Discharge of polluted effluent frequently contaminated sea life, particularly fish, cockles and prawns; therefore, people who eat these contaminated seafood could become seriously ill (WHO 2001).

Santhiya et al. (2011) revealed that the seawater and sediments polluted with discharged treated sewage in Morocco were heavily contaminated with Vibrio sp., Pseudomonas sp., Salmonella spp., Shigella sp. and coliforms group. Al-Sabahi et al. (2009) stated that the concentration of $E$. coli in three surface water bodies located at the downstream of treated sewage generated from STP in Ibb-Yemen was recorded in an average of $2200 \mathrm{CFU} / 100 \mathrm{~mL}$. E. coli increased from zero/100 mL in boreholes located before the plant to $1100 \mathrm{CFU} / 100 \mathrm{~mL}$ boreholes located after the plant. The study revealed the role of the treated sewage in the distribution of pathogenic bacteria into the natural waster system.

The reuse of treated sewage for irrigation is considered as an important alternative water source in the new water management strategy of Middle East countries due to the severe scarcity of water (UN 2012). In Jordan, $13.8 \%$ of all water available for irrigation is sewage effluent, this percentage is predicted to increase to $25 \%$ in 2020 (UN 2003; Al-Enezi et al. 2004). In Kuwait, approximately $43.9 \%$ of the sewage effluents are reused for agricultural irrigation. In Yemen, the farmers use sewage effluents directly from stabilization ponds for irrigation of a wide range of vegetables and crops, especially the Qat farming which represents about 22.3\% of irrigated area (Haidar 2005; Al-Asbahi 2005; ACWUA 2010; Ministry of Agriculture and Irrigation 2012; UN 2012). However, in Tunisia, Morocco and United Arab Emirates (UAE), the treated sewage has been used only for irrigation of gardens in urban centres and tourist facilities (ACWUA 2010). It can be concluded that the reuse of treated sewage for the irrigation in the Middle East countries depends mainly on the geographic area and the development level for each country. Yemen, Jordan, Kuwait and UAE are located in the same geographical area with arid and semi-arid environment; however, UAE is more developed than others. UEA has advanced technologies to the desalination of sea water, while Yemen is the least developed in the field of sewage treatment due to the economic status. Al-Sharabee (2009) reported that $95 \%$ of cultivated area in the zone around SSTP at Yemen $(1.2-6.0 \mathrm{~km})$ depends upon the sewage effluents. Animals in that zone have suffered due to intestinal diseases such as liver calcification, swelling of stomach, intestinal worms, diarrhoea, changes the taste of milk and mouth blister and farmers are infected by many of pathogenic bacteria because they did not wear plant gloves during the irrigation process (Haidar 2005).

The highly treated sewage from STPs is not necessarily a pollutant, rather it represents a nutrient resource for use in crop production (Gopakumar et al. 2000). The application of treated sewage and biosolids at a controlled rate can improve the physical and chemical properties of soils (Katterman and Day 1989). However, the incessant use of sewage effluents and biosolids may produce detrimental effects on soil and crops (US EPA 2004a; Al-Sa`ed 2007).

According to ACWUA (2010), two planning approaches for sewage reuse are applied. First, the intended reuse option determines the water quality and, therefore, the required treatment technology. This approach allows structured planning within a broader wastewater management master plan and gives the greatest flexibility for reuse. Second, the

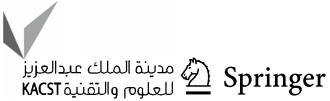


available effluent qualities of existing treatment plants define possible reuse option. This approach is widespread in Middle East countries, but considerably limits the reuse of sewage and the development of new irrigation options.

Biosolids contain water, sand, organic matter, microorganisms, trace metals and other chemicals. Their moisture content, humus-like characteristics and essential nutrients for plants make biosolids beneficial and safe to use as a soil conditioner and fertilizer for agriculture purpose (County 2005). Nevertheless, the concerns in the reuse of treated sewage and biosolids in agriculture lie in the transfer of pathogenic microorganisms to humans directly or indirectly, with the direct transmission of microbial pathogens taking place via the consumption of effluent-irrigated vegetables (Heyman 2004). The irrigation of fresh vegetables by sewage effluents represents the main source of pathogenic bacteria. Some of those pathogens can survive even in washed vegetables (Ronner and Wong 1993). Indirect transmission of infection occurs when sewage effluents are discharged to the rivers, reservoirs and canals that supply irrigation water to farmlands (Cotruvo et al. 2004). Contamination of food, water and feed transmission may also occur through pathogens in biosolids that are spread on land field areas (Carlander 2006; Sahlstrom et al. 2006). The indirect pathway concerns a larger proportion of the human and animal population than the direct infection pathway. Pathogenic bacteria may be taken up by plants and enter into the food chain. Movement through the soil and contamination of groundwater with potential contamination of drinking water, runoff and erosion containing pathogens and contaminating surface water has been reported (Sahlstrom et al. 2006).

The potential of pathogenic bacteria to cause infection in human depends on the ability of bacteria to survive in the environment, which is highly dependent on numbers of environmental factors such as temperature, sunlight, moisture, the availability of organic matter, soil $\mathrm{pH}$, soil particles and the presence of toxic substances as well as competitive organisms that influence bacterial survival in soils and sewage (Ibenyassine et al. 2007). AL-Jaboobi et al. (2013) evaluated the quality and suitability of canal sewage, shallow wells and ponds, in Bani Al-Harth area of Sana'a Yemen, when used to irrigate vegetable production. The results revealed high counts of total coliforms, faecal coliforms, $E$. coli, E. amnigenus, E. intermedius, E. aerogenes, Klebsiella sp., Citrobacter sp., Serratia sp., Proteus spp. Staphylococcus spp., Vibrio spp., Salmonella spp., yeasts and moulds.

On the other hand, the treatment processes of sewage are insufficient to remove antibiotics. Many antibiotics have been detected in large quantities in treated sewage and in surface water receiving effluents (Spongberg and Witter 2008). Antibiotics represent an emerging environmental problem due to their disposal into the aquatic ecosystem, even at minimum inhibitory concentrations (MICs) and increasing of microbial resistance that has occurred as one of the eminent public health concerns of the twenty-first century (Klavarioti et al. 2009: Velickovic-Radovanovic et al. 2009). Irrigation with treated sewage can lead to accumulation of pharmaceutical residues like antibiotics in the irrigated soil (Dalkmann et al. 2012).

Sewage treatment plants are responsible for spreading antibiotic resistance to the natural environment (Laroche et al. 2009; Servais and Passerat 2009; Garcia-Armisen et al. 2011). Therefore, the persistence of antibiotic-resistant strains in the treated sewage should be considered if they are used for land disposal or for water utilisation (Vilanova and Blanch 2005). Al-Gheethi et al. (2013c) investigated the prevalence of antibiotic resistance phenotypes among TC, E. coli, E. faecalis and Salmonella spp. in the treated sewage generated from three sewage treatment plants in Penang Malaysia. The study found that TC and E. coli exhibited high resistance for cephalexin, ampicillin and ciprofloxacin compared to E. faecalis and Salmonella spp., respectively. All E. coli strains, $76.18 \%$ of TC, $66.66 \%$ of $E$. faecalis and $35 \%$ of Salmonella spp. had multi-resistance for antibiotics. Al-Gheethi and Ismail (2014) investigated the antimicrobial resistance among total bacterial counts from sewagetreated effluents. The report revealed that about $83.82 \%$ of the bacterial isolates were multi-resistant (resistant to three antibiotics or more). Gram-positive bacteria exhibited more multi-resistance to antibiotics (cephalexin, amoxicillin, ampicillin and cefuroxime) than Gram-negative bacteria. Based on these studies it can be indicated that the sewage effluents represent a rich source of antimicrobial resistance bacteria, perhaps due to the high nutrients contents.

\section{Frequently occurred pathogenic bacteria in the treated sewage and biosolids}

Treated sewage and biosolids contain many pathogenic microorganisms, the most important are those transmitted by the faecal-oral route, which includes bacteria, viruses and parasites (US EPA 2003; Wen et al. 2009). However, bacteria represent then concern due to their ability to increase in the environment because it does not require a host cell for replication (Ceustermans et al. 2007). The actual species and density of pathogenic bacteria in sewage depend on public health, the size of the local community and the presence of hospitals, factories, as well as on sewage treatment processes (Harrison et al. 1999; US EPA 2003; Bitton 2005a).

There is a wide spectrum of pathogenic bacteria that has been detected in the treated sewage and biosolids, many of which are enteric in nature (Toze 1997). V. cholera, Leptospira spp., Salmonella spp., C. jejuni, E. coli O157:H7, Y. enterocolitica and Shigella sp. are considered as a major 
concern which could result in disease to the general population, while B. cereus, Enterobacter spp., Klebsiella spp., $C$. perfringens, L. monocytogenes, $P$. aeruginosa, S. aureus and Streptococcus spp. are the minor concerns which are considered opportunistic pathogens that cause disease only in debilitated or immunologically compromised individuals (Kowal 1983; US EPA 1988; Synnott et al. 2009; Dungeni et al. 2010; Ellafi et al. 2010; Coronel-Olivares et al. 2011).

Markosyan et al. (2002) detected different genera of Klebsiella, Enterobacter, Hafnia, Serratia, Proteus, Providencia and Escherichia in the biosolids. Younis et al. (2003) isolated Salmonella spp., Shigella spp., Vibrio spp., Staphylococcus spp. and Listeria spp. from STP located in Aswan, Egypt. Lisle et al. (2004) observed that the untreated sewage at Memurdo station, Antarctica, contained relatively high concentrations of total coliforms, faecal coliforms, E. coli, enterococci and C. perfringens. Al-Zubeiry (2005) detected S. aureus, S. pneumonia, E. coli, Salmonella spp. and $P$. aeruginosa in raw sewage and secondary effluent generated from STP in Ibb, Yemen. El-Lathy et al. (2009) isolated Salmonella spp., Listeria spp and Vibrio spp. (V. vulnificus, $V$. parahaemolyticus and $V$. cholera) from sewage samples from oxidation pond in El-Sadat, Egypt, and biosolids from Zenin sewage treatment plant at Giza, Egypt. Ye and Zhang (2011) studied the presence of pathogenic bacteria in biosolids from 14 STPs in China, USA, Canada and Singapore. The study detected Aeromonas veronii, A. hydrophila, $C$. perfringens and $C$. Diphtheria as most common. Bala et al. (2012) investigated pathogenic bacteria in pharmaceutical wastewater in Nigeria. They noted that E. coli, Salmonella sp., Klebsiella sp., P. aeruginosa, S. aureus, P. vulgaris, Clostridium sp. and E. faecalis were predominant.

Al-Gheethi et al. (2013a) reported that K. pneumonia, E. coli, Shigella sp., Salmonella spp., S. aureus, E. faecalis and $P$. aeruginosa are abundant in three STPs in Malaysia. Al-Gheethi et al. (2014) also investigated the bacterial diversity in treated sewage and biosolid samples generated from five STPs in Yemen. The authors isolated hundred and sixty bacterial strains. Among those, E. coli was the most common, followed by S. faecalis, K. pneumonia, E. aerogenes, $S$. typhi, S. typhimurium, $S$. sonni and $Y$. pestis. The most concerned bacteria are discussed below;

\section{Salmonella spp.}

Salmonella spp. are rod-shaped, Gram-negative, nonspore-forming, facultatively anaerobic bacteria, discovered by Salmon in 1880. This group consists of a range of very closely related bacteria that belongs to the genus Salmonella and the family Enterobacteriaceae. Salmonella spp. exhibit psychrotrophic properties and actively grow within a wide temperature range $\left(10-54{ }^{\circ} \mathrm{C}\right)$ (Woteki and Kineman 2003).
Salmonella spp. are resistant microorganisms that are readily adapt to extreme environmental conditions and have the ability to survive under hostile environmental conditions (Espigares et al. 2006; Alvarez-Ordonez et al. 2011). These characteristics make them the indicator of choice for monitoring the effectiveness of biosolid pathogen reduction (US EPA 1995). US EPA (2003) also demonstrated that Salmonella spp. are bacteria of great concern as well as good representatives of the reduction of other bacterial pathogens because they are typically present in higher densities than other bacterial pathogens and have the ability to survive for a long time in the environment.

Salmonella spp. are the most prevalent bacterial pathogens of public healthcare concern that are frequently found in sewage (Dumontet et al. 2001; Espigares et al. 2006). Salmonella spp. can cause diseases to all organisms from insects to mammals (Bohm 2004). Enteric fever is a collective term given to the invasive infections caused by $S$. typhi and S. paratyphi causes paratyphoid fever. S. typhi is a pathogen that only has humans as its natural host (Heritage et al. 2003).

Burtscher and Wuertz (2003) reported that about $48 \%$ of the 46 biosolids samples tested were positive for Salmonella spp. which could be detected in both untreated and treated waste samples during intermediate stages of treatment. However, S. stanley was the only pathogen isolated after the thermophilic anaerobic digestion (Sahlstrom et al. 2004).

\section{Shigella sp.}

This is a genus of gamma-Proteobacteria in the family Enterobacteriaceae (Brenner et al. 2005), discovered by Kiyoshi Shiga in 1896. They are rod-shaped, Gram-negative, nonspore-forming, non-motile bacteria that are very closely related to $E$. coli and only humans are always the host (Geldreich 1996). Members of the Shigella genus (S. dysenteriae, $S$. boydii, S. flexneri and $S$. sonnei) are the major cause of dysentery, diarrhoea, fever, vomiting and cramps, which frequently occurred in countries that lack potable drinkable water such as India (Niyogi 2005). The dysentery bacilli are the most common infectious diseases in third world countries and among travellers to tropical countries (Vila et al. 1994). Shigella spp. are the second pathogenic bacteria that cause intestinal diseases in China (Peng et al. 2002).

The infectious dose for Shigella sp. was determined to be as few as 10-100 organisms (Fratamico et al. 2005) and the waterborne transmission of shigellosis was documented epidemiologically (Alamanos et al. 2000). Shigella sp. was isolated from pharmaceuticals wastewater, sewage effluents and biosolids (Bala et al. 2012; Al-Gheethi et al. 2013a). Chen et al. (2012) found that Shigella sp. survived more than Salmonella sp. and E. coli during mesophilic anaerobic digestion of sludge. However, it has been reported previously 
that Shigella sp. does not appear to survive long in the environment (Gebra 1996).

\section{Escherichia coli 0157:H7}

Escherichia. coli is a rod-shaped Gram-negative bacterium, which belongs to the family Enterobacteriaceae. They are facultative, oxidase-negative anaerobes and produce gas from glucose. E. coli is a member of the physiological gastrointestinal flora bacterium species for human and warm-blooded animals. Additionally, it belongs to the normal intestinal flora and a facultative pathogen for human being (Kaper et al. 2004). However, some E. coli serotypes are pathogenic, among them enterohaemorrhagic strain $E$. coli $\mathrm{O} 157: \mathrm{H} 7$ which causes gastrointestinal disorders such as bloody diarrhoea, cramping and abdominal pain and the infectious "hemolytic uremic syndrome" (Fijalkowski et al. 2014). E. coli O157:H7 was first reported as a gastrointestinal pathogen in 1982 (Riley et al. 1983), they are able to survive in environment for long time without a host (Qing et al. 2010). Isolation of $E$. coli from surface water, treated sewage and biosolids has been reported by many investigators (Al-Zubeiry 2005; Jokinen et al. 2010; Al-Gheethi et al. 2013a; Al-Gheethi et al. 2014).

\section{Clostridium perfringens}

Clostridium. perfringens is an obligate anaerobic Grampositive bacterium, bacilli-shaped and endospore forming. It is a member of the Sulfite-Reducing Clostridia (SRC) group. C. perfringens has been isolated from sewage by many researchers (Lisle et al. 2004; Ye and Zhang 2011), because it represents $0.5 \%$ of the faecal microflora (Leeming et al. 1998; Payment et al. 2002). Payment and Franco (1993) recommended this bacterium as an indicator for the presence of Giardia cysts in water treatment plants as well as to evaluate the quality of recreational waters (Fujioka 1997). Suresh et al. (1996) confirmed that the use of C. perfringens as well as faecal coliforms and faecal streptococci could serve as an excellent approach for identifying the presence of airborne pathogens and determining their origins or sources associated with the treatment and disposal of wastewater and biosolids.

Lepeuple et al. (2004) reported that the C. perfringens is common in raw sludge and resistant to heat, and hence their removal can be related to removal of spore-forming species such as Bacillus sp. C. perfringens has been reported as resistant to oxidizing agents and to UV disinfection (Alonso et al. 2004). Rouch et al. (2011) indicated that $C$. perfringens appeared to be a conservative indicator during their study on the air drying of sludge generated from two STPs in Victoria, Australia. However, some authors stated that the hardy spores of this bacterium make it too resistant to be useful as an indicator organism. Thus, it could be useful as an indicator of past pollution and as a trace to follow the fate of pathogens (Bitton 2005b). Vierheilig et al. (2013) investigated $C$. perfringens in different faecal sources at Austria for 3 years. They stated that $C$. perfringens was not suitable as indicator of faecal pollution but they suggested that it could be used as a tracer for excreta from human sewage.

\section{Faecal indicator bacteria}

Analytical techniques for the direct detection and identification of many types of pathogenic bacteria in the sewage effluents require well-trained technicians. These techniques are usually unpredictable, difficult, costly and time consuming. The faecal organisms which are used as pathogenic indicator can determine the relative risk of biosolids (Toze 1997; Wen et al. 2009).

The indicator bacteria are adapted to living in the gastrointestinal tract and can be harboured in other different habitats, such as a septic system or sewage collection system (Gordon et al. 2002). Indicator organisms are used as models for the behaviour of pathogens, for example, to determine the efficiency of treatment processes, where their growth characteristics (temperature and $\mathrm{pH}$ ) are similar to those of numerous pathogens for which detection and quantification are difficult or sometimes impossible (Lepeuple et al. 2004).

Many bacteria have been studied for their suitability as faecal indicators (Ashbolt et al. 2001; US EPA 2007). The first bacterial species, which had been used as faecal indicators, were K. pneumoniae and K. rhinoscleromatis, which was suggested by Von Fritsch in 1880 (Geldreich 1978). However, many bacterial species were also suggested as indicators. Dancer (2004) has proposed S. aureus as an indicator of hospital hygiene for microbiological standards. Jin et al. (2013) used S. aureus as indicator to evaluate the hydrothermal treatment process in achievement of the hygienic safety of food waste.

Al-Gheethi et al. (2013a) studied the correlation between the frequencies and the numbers of faecal indicators and pathogenic bacteria. They found that $E$. coli has been correlated significantly with all pathogenic bacteria investigated (K. pneumonia, P. aeruginosa, Shigella sp. and Salmonella spp.), E. faecalis has correlated by $75 \%$ while total coliforms and faecal coliforms correlated by $50 \%$ with pathogens under study.

In general, the criteria for selection of faecal indicator organisms have been documented as follows (Cooper and Olivieri 1998; Dumontet et al. 1999; Bitton 2005a; Myers et al. 2007):

1. Should be a member of the Enterobacteriaceae family.

2. The presence of faecal indicators should be associated with the presence of pathogens. 
3. Numbers should be greater than that of the pathogens.

4. It should be resistant to the disinfection processes as the pathogens.

5. It should not increase in the environment.

6. Should be easily detected by simple techniques.

7. Should be non-pathogenic.

Faecal indicators organisms are discussed below;

Total coliforms are groups belonging to Enterobacteriaceae and include the aerobic and facultative anaerobic, rod-shaped, non-spore-forming, Gram-negative bacteria that ferment lactose with gas production within $48 \mathrm{~h}$ at $35^{\circ} \mathrm{C}$ (APHA 1989). These characteristics are suitable for the identification of this group and no confirmatory tests are required (Edberg et al. 1990).

Total coliforms include four genera, Escherichia sp., Enterobacter sp., Klebsiella sp. and Citrobacter sp. Some members of this group, e.g., Klebsiella sp. may grow in industrial waste. They are the historic indicators of faecal contamination since 100 years ago (Cooper and Olivieri 1998). Total coliforms are one of the best indicators for treatment efficiency of sewage treatment plants (Bitton 2005b).

Faecal coliforms (FC) are classified under the group of total coliforms and are more faecal specific in origin and include E. coli and other faecal (or thermotolerant) coliforms that can ferment lactose at $44.5^{\circ} \mathrm{C}$ (Kimberly et al. 2005). The presence of these organisms more accurately correlates with warm-blooded animal faecal discharges. However, even this group contains a genus, Klebsiella with species that are not necessarily faecal in origin. Klebsiella sp. is commonly associated with textile, pulp and paper mill wastes (US EPA 1986a).

According to the US EPA (1992), FC is faecal bacteria that are used as indicators to show probable presence of pathogenic bacteria, because they are easily detected and their densities decline in the same proportion as pathogens during the treatment process. The EPA Part 503 regulations "Standards for the use or disposal of sewage sludge" have established pathogen reduction requirements for FC (US EPA 2003).

For recreational waters, FC was the primary bacterial indicator until 1986, when the EPA began recommending $E$. coli and enterococci as better indicators of health risk from water contact (US EPA 1986a). FC is still being used in many states of USA as the indicator bacteria. However, Byappanahalli and Fujioka (1998) reported that tropical soil environments such as in Hawaii provide sufficient means to support the growth of FC and E. coli. Polo et al. (1998) have shown poor to no correlation between E. coli and Salmonella spp. to FC. Hörman et al. (2004) reported that there was no correlation between E. coli and Campylobacter spp.

Enterococci bacteria have been considered useful as secondary indicators of faecal contamination (APHA
1998). However, Bitton (2005b) reported that enterococci are good indicators of faecal pollution like faecal coliforms. Enterococcus species (E. faecium, E. faecalis, E. avium, E. gallinarum and E. durans) have the ability to grow at both 10 and $45{ }^{\circ} \mathrm{C}$, at high pH 9.6 and in medium containing 6.5\% $\mathrm{NaCl}$ (Cooper and Olivieri 1998; Carvalho and Teixeira 2002). This group has been suggested as useful for indicating the presence of viruses, particularly in sludge, sea water and biosolids (Bitton 2005b), because these organisms are relatively easy to enumerate and survive longer than faecal coliforms (Mote et al. 2012).

Enterococci along with faecal coliforms have been used to differentiate human faecal contamination from that of other warm-blooded animals based on FC/FS ratio, if the ratio less than 1.0 this means that the source of faecal contamination are all warm-blooded animals other than man, if the ratio was 4.0 , this means the source of faecal contamination is human. Intermediate ratios indicate contamination from both man and animals (Young and Thackston 1999; Baudišová 2009). Enterococci are a more reliable indicator than faecal coliforms for the detection of microbial pollution as they are more resistant to the environment than faecal coliforms (Celico et al. 2004). It has been frequently considered as reference microorganism for thermal treatments to be applied in pasteurized foods (Smith et al. 1990; Ghazala et al. 1991). However, US EPA (US 2004a) and WHO (1989) did not regulate standards limits of enterococci in treated sewage if the effluents is to be reused for irrigation or groundwater recharge.

\section{Regulations of treated sewage and biosolids}

To maintain safe reuse of sewage treated effluents, WHO (1989) reported that the geometric mean of FC should be less than 1000 cells/100 mL (Table 1), these standards are also used in Jordan and Palestine. However, US EPA (2004b) recommended more stringent standards for sewage-treated effluents. FC should not exceed 14 cells/100 mL (Table 2). In Saudi Arabia, the standards for sewage effluents reuse in agricultural irrigation are issued by the Ministry of Municipal and Rural Affairs (MMRA). According to those standards, FC should be less than 2.2 cells/100 mL of unrestricted irrigation and less than 1000 cells/100 mL of restricted irrigation (Al-Jasser 2011). The EPA part 503 regulations for the reuse of biosolids (CFR 1995) divided stabilization biosolids into "Class A" and "Class B". Class A biosolids must meet either FC limit of less than 1000 MPN g-1 TS or less than 3 Salmonella/4 g TS. Class B biosolids should be meet a FC limit of less than $10^{6} \mathrm{MPN} \mathrm{g}^{-1} \mathrm{TS}$. The standards for reuse of 
Table 1 Guidelines for using treated wastewater in agriculture (WHO 1989)

\begin{tabular}{|c|c|c|c|c|c|}
\hline Category & Reuse conditions & Exposed group & $\begin{array}{l}\text { Intestinal nematode } \\
\text { (arithmetic mean no } \\
\text { eggs/L) }\end{array}$ & $\begin{array}{l}\text { Coliforms } \\
\text { (geometric } \\
\text { mean/100 mL) }\end{array}$ & $\begin{array}{l}\text { Wastewater treatment expected } \\
\text { to achieve the required microbio- } \\
\text { logical guideline }\end{array}$ \\
\hline A & $\begin{array}{l}\text { Irrigation of crops likely to be } \\
\text { eaten uncooked, sports fields, } \\
\text { public parks }\end{array}$ & $\begin{array}{l}\text { Workers, } \\
\text { consumers, } \\
\text { public }\end{array}$ & $\leq 1$ & $\leq 1000$ & $\begin{array}{l}\text { A series of stabilization ponds } \\
\text { designed to achieve the micro- } \\
\text { biological quality indicated, or } \\
\text { equivalent treatment }\end{array}$ \\
\hline $\mathrm{B}$ & $\begin{array}{l}\text { Irrigation of cereal crops, } \\
\text { industrial crops, fodder crops, } \\
\text { pasture and trees }{ }^{\mathrm{d}}\end{array}$ & Workers & $\leq 1$ & $\begin{array}{l}\text { No standard } \\
\text { recommended }\end{array}$ & $\begin{array}{l}\text { Retention in } \\
\text { stabilization ponds } \\
\text { for } 8-10 \text { days or equivalent hel- } \\
\text { minthic and FC removal }\end{array}$ \\
\hline $\mathrm{C}$ & $\begin{array}{l}\text { Localized irrigation of crops } \\
\text { in category B if exposure to } \\
\text { workers and the public does } \\
\text { not occur }\end{array}$ & None & Not applicable & Not applicable & $\begin{array}{l}\text { Pre-treatment as required by irri- } \\
\text { gation technology, but not less } \\
\text { than primary sedimentation }\end{array}$ \\
\hline
\end{tabular}

${ }^{a}$ Ascaris and Trichuris species and hookworms

${ }^{\mathrm{b}}$ During the irrigation period

${ }^{\mathrm{c}} \mathrm{A}$ more stringent guideline $(200 \mathrm{FC} / 100 \mathrm{~mL})$ is appropriate for public lawns, such as hotel lawns, with which the public may come into direct contact

${ }^{\mathrm{d}}$ In the case of fruit trees, irrigation should cease 2 weeks before fruit is picket, and no fruit should be picked off the ground. Sprinkler irrigation should be used

Table 2 Microbiological requirements for reclaimed water (US EPA 2004b)

\begin{tabular}{lll}
\hline Type of use & Treatment & Reclaimed water quality \\
\hline $\begin{array}{l}\text { Urban uses, food crops eaten raw, recreational } \\
\text { impoundments }\end{array}$ & Secondary, filtration, disinfection & $\begin{array}{l}\mathrm{pH}=6-9 \\
\text { no detectable FC/100 } \mathrm{mL}^{\mathrm{a}}\end{array}$ \\
$\begin{array}{l}\text { Restricted access area irrigation, processed } \\
\text { food crops, non-food crops, aesthetic }\end{array}$ & Secondary, disinfection & $\mathrm{pH}=6-9$ \\
$\begin{array}{l}\text { impoundments, construction uses, industrial } \\
\text { cooling, environmental reuse }\end{array}$ & & \\
$\begin{array}{l}\text { Groundwater recharge of potable aquifers by } \\
\text { spreading }\end{array}$ & $\begin{array}{c}\text { Site-specific secondary and disinfection } \\
\text { (minimum) }\end{array}$ & $\begin{array}{c}\text { Site-specific meet drinking water standards } \\
\text { after percolation through vadose zone }\end{array}$ \\
$\begin{array}{c}\text { Groundwater recharge of potable aquifers by } \\
\text { injection, augmentation of surface supplies }\end{array}$ & $\begin{array}{c}\text { Includes: secondary, filtration, disinfection, } \\
\text { advanced wastewater treatment }\end{array}$ & \begin{tabular}{c} 
Includes: $\mathrm{pH}=6-8.5$ no detectable FC/100 mL $\mathrm{mL}^{\mathrm{a}}$ \\
\hline
\end{tabular} \\
\hline
\end{tabular}

${ }^{a}$ Based on 7-day median value. Should not exceed $14 \mathrm{FC} / 100 \mathrm{~mL}$ in any sample

${ }^{\mathrm{b}}$ Based on 7-day median value. Should not exceed $800 \mathrm{FC} / 100 \mathrm{~mL}$ in any sample

sewage effluents and biosolids issued out by the Yemen agricultural sector have focused on the basic parameters of sewage such as COD, BOD, TS and TSS. However, these standards are neither met nor controlled, because most of STPs are overloading, and Yemeni laboratories are not equipped to measure all mentioned parameters (ACWUA 2010).

\section{Further treatment of treated sewage}

Recent studies revealed that detectable amounts of pollutants remain in sewage effluents, even after secondary sewage treatment processes are performed. These pollutants could be transmitted into rivers and other environment during the final disposal or reuse of the effluent (Spongberg and Witter 2008). Rizzo et al. (2013) reported that conventional disinfection processes might not be effective in the inactivation of antibiotic-resistant bacteria. Therefore, to achieve safe reuse of sewage-treated effluents, advanced treatment technologies have been applied to reduce various potentially harmful compounds that could not be effectively removed by conventional treatment processes. Advanced treatment technologies have high potential to produce an effluent of higher quality than normally achieved by secondary treatment processes (Zhou and Smith 2002; Jin et al. 2013). The techniques used for this 
purpose include reduction of pathogens by disinfection process (Al-Rekabi et al. 2007).

\section{Disinfection processes of sewage-treated effluents}

The concentrations of faecal indicator bacteria in untreated sewage are $8 \log _{10} \mathrm{CFU} / 100 \mathrm{~mL}$ for TC, $7.48 \log _{10}$ $\mathrm{CFU} / 100 \mathrm{~mL}$ for $\mathrm{FC}$ and $6.6 \log _{10} \mathrm{CFU} / 100 \mathrm{~mL}$ for enterococci (Wilén et al. 2012). The conventional treatment processes for sewage (primary and secondary processes) remove 95-99\% of most microorganisms (Koivunen et al. 2003). However, their numbers in the sewage effluent usually remain higher than $4 \log _{10} \mathrm{CFU} / 100 \mathrm{~mL}$ (Luczkiewicz et al. 2010). The stabilization pond was reported to reduce $84 \%$ of total coliform, $96 \%$ of faecal coliform and $89 \%$ of enterococci (Reinosoa et al. 2008). The reduction efficacies of faecal indicator bacteria by the septic tank and oxidation pond were reported to be 15 and 38\% for FC and 11 and 16\% for FS, respectively (Samhan et al. 2007).

Many studies have found that the concentrations of faecal indicators in the treated sewage and biosolids are still more than the standard limits of US EPA and WHO guidelines. Heng et al. (2006) found that the concentrations of TC in the treated sewage generated from two-oxidation ponds at Kajang and UKM-Malaysia were 8.95 and $8.58 \log _{10}$ CFU/100 mL. Siti Khadijah et al. (2013) reported that the concentration of FC in the treated sewage from the oxidation ponds in USM Engineering Campus, Malaysia, were also more than WHO guidelines, where FC concentrations ranged from 2.36 to $5.57 \log _{10} \mathrm{CFU} / 100 \mathrm{~mL}$. Al-Gheethi et al. (2013a) revealed that the concentrations of FC at the three STPs in Penang, Malaysia were greater than the standard limits recommended by the WHO guideline for use of treated wastewater in agriculture and US EPA microbiological requirements for wastewater reuse.

According to those studies, it can be concluded that the treated sewage still contains high concentrations of pathogenic bacteria even after sewage treatment processes. The high bacteria levels in the natural water that received sewage-treated effluent lead to increase in BOD, resulting in depletion of oxygen levels required for the various types of living organisms supported by the estuary. Therefore, treated sewage needs to undergo further treatment to reduce the density of pathogenic bacteria to achieve a favourable sanitary effluent quality (Koivunen et al. 2003; Jin et al. 2013). Disinfection process of effluents increases the reduction of pathogens for high-quality reuse (Crook 1998; Neis and Blume 2002). The tertiary treatment is able to achieve the guidelines of WHO and US EPA standards for pathogen inactivation. The development of a tertiary treatment process includes all techniques that offer significantly higher removal of pathogenic bacteria. The most common disinfection processes of treated sewage are discussed below.

\section{Chlorination}

Chlorination is the most common method used for disinfection of treated sewage in Middle East countries because it is easily applied, readily available and cheaper than other oxidising agents. It can also be used to inhibit bacteria growth in treated sewage (Gomez et al. 2006). Tree et al. (2003) found that chlorination has significant effect in the reduction of E. coli and E. faecalis in sewage-treated effluents. However, the occurrence of pathogenic bacteria in treated sewage after chlorination has been observed. Dungeni et al. (2010) stated that despite high free chlorine residual concentrations in sewage-treated effluents, the survival of E. coli, $S$. typhimurium and $V$. cholerae was significantly high and they suggested an upgrading of the STPs by other processes to increase the inactivation of pathogenic bacteria. CDPH (2009) reported that the chlorination disinfection system is the primary disinfection process, and the whole disinfection of reclaimed water should be performed by the pasteurisation system.

Moreover, one main disadvantage for utilization of chlorine disinfection is the presence of free and combined chlorine residues which is being toxic to aquatic organisms. Therefore, the requirement to de-chlorinate or to remove chlorine residues from the treated sewage before it is discharged into the environment has increased in recent years due to the potential health hazards of nitrosodimethylamine (NDMA) which is reported as a probable human carcinogen (Pehlivanoglu-Mantas et al. 2006).

\section{Ozonation}

One of the most effective disinfectants used in water disinfection is ozone. This is because ozone has high ability to destroy pathogenic cells through an irreversible physiochemical action. Ozonation destroys the cell wall of the bacteria as well as semi-permeable membrane. The destruction in the cell wall and membrane leads to the bacterial cell death (Facile et al. 2000). Tripathi et al. (2011) claimed that $5 \mathrm{~min}$ of exposure at a concentration of $10 \mathrm{mg}$ ozone $\mathrm{L}^{-1}$ was suitable for the inactivation of pathogenic bacteria by $95-98 \%$. Previous studies reported that ozone effectively removes TC and FC from sewage-treated effluents. Battaler et al. (2005) found that the ozone disinfection of secondary effluents at concentration $4.7 \mathrm{mg} \mathrm{L}^{-1}$ for $5 \mathrm{~min}$ had eliminated $\mathrm{TC}$ and FC. At $21.4 \mathrm{mg} \mathrm{L}^{-1}$ the bacteria that resisted for chlorine such as $P$. aeruginosa decreased by $2 \log$ reduction after 5 min of disinfection process by ozone.

Disinfection of treated sewage by ozone is applied because the use of ozone is cheap and low energy is needed. Nonetheless, the effectiveness of disinfection using ozone depends on the ozone dose, the ozone demand, the quality

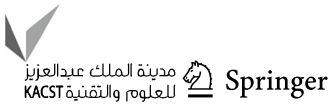


of the effluent and the transfer efficiency of the ozone system (Paraskeva and Graham 2002). The COD and total suspended solids (TSS) of treated sewage might affect the efficiency of disinfection process by ozone (Janex et al. 2000). The properties of the treated sewage might induce the microbial resistance for the ozone as noted for Enterococcus sp., Clostridium sp. and Salmonella spp. which exhibit resistance to ozonation (Xu et al. 2002).

In USA, the disinfection of drinking water by ozonation process is more attractive disinfection method due to the promulgation of the EPA's restrictions of disinfection by-products (DBPs) permitted in America's drinking water attributable to chlorination. Nevertheless, ozonation can also lead to the formation of potentially harmful by-products inclusive of bromate ions $\left(\mathrm{BrO}_{3}\right)$, aldehydes and peroxides. Vital et al. (2010) reported that the major concern associated with the ozone application lies in the increase in microbial regrowth due to the oxidation process which generates the assimilable organic carbon (AOC).

\section{UV irradiation}

Disinfection by ultraviolet irradiation has been reported as a suitable technology for inactivating coliforms and Salmonella spp. (Keller et al. 2003). The principle of a UV disinfection system is to destroy the genetic material of the bacterial cell and thus retard its ability to reproduce (US EPA 1986b). The effectiveness of a UV disinfection system depends on the characteristics of the effluents including the concentration of the sewage effluent, the intensity of the UV radiation and the time of the treatment (Kollu and Ormeci 2012).

Nasser et al. (2006) revealed that the treated sewage disinfected by UV is suitable for the unrestricted irrigation of food crops (FC < $1000 \mathrm{CFU} / 100 \mathrm{~mL}$ ). Dungeni et al. (2010) suggested UV disinfection as an additional treatment process of effluents to increase the effective inactivation and removal of pathogenic bacteria and viruses. However, Alonso et al. (2004) found that Clostridium spp., showed a greatest degree of resistance to UV treatment. Munir et al. (2010) indicated that the disinfection of effluents by UV process did not contribute to the significant reduction of antibiotic-resistant bacteria. Ting et al. (2011) observed a re-growth and repair potential of $E$. coli, FC and B. subtilis in reclaimed water after UV disinfection. Wang et al. (2012) suggested that the higher number of particles in the treated sewage might have protected the bacteria against UV damage. Based on those studies, it can be indicated that UV technology might have a limitation for the sewage disinfection. But it has to be motioned that the disinfection processes of the treated sewage might be more effective as two methods have been used simultaneously such as the solar disinfection which depends on the UV radiation, photo-oxidation and temperature (Sect. "Solar disinfection (SODIS)").

\section{Filtration technology}

Filtration systems are designed to remove very small particulate or "suspended" solids from the treated sewage. OnnisHayden et al. (2011) evaluated sand filtration technology in the disinfection of sewage generated by STPs and found that the $E$. coli concentration reduced to below 2 logs in the filtered sewage-treated effluents. Despite its high efficiency in the removal of pathogenic bacteria and producing effluents with good microbiological quality, the effluents would not be considered as sterile, since contamination of permeation zones gave rise to the presence of pathogenic bacteria (Gomez et al. 2006). At the same time, the membrane filtration systems are expensive with regard to construction and maintenance (Neis and Blume 2002). Different filtration systems have been developed which depend on the utilization of raw and low-cost materials such as sands and ceramic (Mohamed et al. 2016). These systema have exhibited high efficiency in the reduction of the main parameters of wastewater such as COD, BOD and TSS, but their efficiency in the reduction of pathogenic bacteria still needs more investigation.

\section{Storage of treated sewage}

Storage systems are used typically for accumulating wastewater before its ultimate disposal, or for temporarily holding batch streams before treatment (US EPA 1989). A storage basin was also used for treating effluent storage, especially during winter in temperate country. The stored effluents will be released to environment normally during the rainy season where the dilution rate is higher (Al-Gheethi et al. 2017).

Storage of sewage has become the option selected in European and Mediterranean countries because of the advantages they present in comparison with other treatment alternatives. This includes the coupling of two purposes: stabilization and seasonal regulation to regulate between sewage production and demand of treated wastewater for irrigation (Barbagallo et al. 2003).

Al-Gheethi et al. (2013a) studied the effect of storage of treated sewage on survival of faecal indicators and Salmonella spp. and the susceptibility of these bacteria to antibiotics during the storage period. The treated sewage was stored at room temperature for 28 days. The study noted that FC density in stored effluents dropped from $5.182 \log _{10}$ CFU/100 mL to below $2 \log _{10}$ CFU/100 mL after 28 days and the treated sewage met WHO guidelines. E. faecalis decreased to less than detection limits during the storage period of 1 week. However, they observed that TC and Salmonella spp. which have survived during the storage 
period acquired more resistance to antibiotics. At the end of the storage period, TC and Salmonella spp. were resistant to cephalexin, cefuroxime, ampicillin and amoxicillin. The study concluded that the storage system of treated sewage would increase the distribution of antimicrobial resistance among bacterial population after the disposal or reuse of treated sewage for agricultural purposes. Indeed, the efficiency of the storage system on the reduction of pathogenic bacteria depends mainly on the storage temperature, the storage system at the room temperature might be effective for the reduction of pathogenic bacteria but it needs long time to achieve high reduction of pathogens and then to meet the international standards required for the sewage disposal or reuse of the sewage for the irrigations (Al-Gheethi et al. 2017). The mechanism which takes place in the storage system and leads to the reduction of pathogens might be the competition process between microorganisms due to the deficiency in the nutrients contents (Al-Gheethi et al. 2016a).

\section{Heat pasteurization}

Heat disinfection is a proven technology in Europe that requires skills such as boiler operation and the understanding of high-temperature and -pressure processes. The EPA Part 503 regulations (US EPA 2003) consider pasteurisation as a process to further reduce pathogen (PFRP). CDPH (2009) reported that the use of pasteurisation is recognised as an acceptable disinfection process for meeting the inactivation criteria of coliform bacteria. It is a known fact that pathogenic bacteria are inactivated during exposure to heat, especially when the temperature of the treatment is above the optimum temperature of growth (Himathongkham and Riemann 1999). Lucero-Ramirez (2000) reported that pathogenic bacteria are reduced to less than detectable levels in properly operated heat-drying systems. Alcalde et al. (2003) indicated that the retention time and temperature are the most important factors for the removal of pathogenic bacteria.

Bacteria can be classified into different groups based on optimum temperature. Most human pathogenic bacteria are mesophilic $\left(10-40{ }^{\circ} \mathrm{C}\right)$ with an optimum temperature of $37^{\circ} \mathrm{C}$. Metabolic enzymes of bacteria denature and inactive when exposed to temperature above its optimum. This eventually led to the death of the bacterial cell. Removal of faecal indicators (enterococci and E. coli) in piggery effluents to achieve hygiene standards could easily be met by treatment at $60{ }^{\circ} \mathrm{C}$ (Cunault et al. 2011). Al-Gheethi et al. (2013a) investigated the heat treatment of treated sewage at different temperatures $\left(45,55\right.$ and $\left.65^{\circ} \mathrm{C}\right)$. They found that the sewage effluents disinfected at $45^{\circ} \mathrm{C}$ for $192 \mathrm{~h}, 55^{\circ} \mathrm{C}$ for $24 \mathrm{~h}$ and $65^{\circ} \mathrm{C}$ for 30 min have met standard limits regulated by the
US EPA. The sewage effluents can be reused for irrigation purpose.

\section{Solar disinfection (SODIS)}

SODIS-based technologies are an efficient approach for the reduction of pathogenic microorganism in the water due to high availability of solar radiation and sustainable nature of these water treatment methods (Gomez-Couso et al. 2009). According to WHO (2002), SODIS depends on using transparent polyethylene terephthalate (PET) bottles and then exposing to the sun for a period between 4 and $8 \mathrm{~h}$. Meierhofer and Wegelin (2002) recommended that PET bottles containing untreated raw water should be exposed to direct sunlight for at least $6 \mathrm{~h}$. Bacteria, viruses, Giardia and Cryptosporidium cysts, and parasite eggs could be inactivated through the combination of ultraviolet radiation and elevated water temperature. Large field tests of SODIS were conducted in a number of countries in South America, Africa, and Asia in the 90s (Acra 1990).

The destruction of the bacterial cells takes place due to the combination of UV radiation and high temperature which has high potential to destroy the cell membrane (AlGheethi et al. 2015). However, SODIS has no efficiency for the reduction of chemical pollutants in the water. The sunlight has been reported as the single most important disinfection factor in the stabilization pond (Leduc and Gehr 1990; Maynard et al. 1999). Three main mechanisms are involved during the SODIS simultaneously, included the absorption of solar UV-B by microorganism DNA which causes direct damage by pyrimidine dimer formation. The process is independent of oxygen and other pond conditions. The second mechanism depends on the absorption of UV-B and some shorter wavelength UV-A by cell constituents including DNA (called endogenous photo-sensitisers). The activated constituents react with oxygen to form highly reactive photo-oxidising species that damage genetic material within the cell or viral particle. The third mechanism involves absorption of a wide range of UV and visible wavelengths in sunlight by extra-cellular constituents of the pond medium (exogenous photo-sensitisers-notably humic material) (Jagger 1985).

Al-Gheethi et al. (2013b) investigated the effect SODIS on the survival of FC, E. faecalis, Salmonella spp. and $S$. aureus in treated sewage inside PET bottles. The study revealed high reduction of FC, Salmonella spp. and $S$. aureus by more than $4 \log _{10} \mathrm{CFU} / 100 \mathrm{~mL}$ after $6 \mathrm{~h}$, while these pathogens were below the detection limits after $8 \mathrm{~h}$ as detected by using the enrichment medium. The treated sewage met US EPA (2004a) standards after $6 \mathrm{~h}$, where FC counts were less than $14 \mathrm{CFU} / 100 \mathrm{~mL}$. SODIS has several advantages to the reduction of faecal indicator in treated sewage compared to the others techniques such as

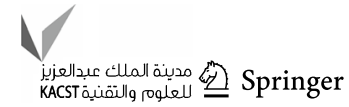


chlorination, UV irradiation and ozonation. SODIS is compatible to meet the standards of the disinfection processes of sewage treated effluents. This is because SODIS is effective, more efficient, easily implementable and lower cost. SODIS is a natural process that produces no toxic by-product (AlGheethi 2014).

SODIS is more appropriate to be applied in the developing countries that do not have the facilities to build typical sewage treatment plants. The climate of many Middle East countries such as Yemen, Saudi Arabia, Oman, Jordan and Egypt is semi-arid to arid and the temperatures during summer season vary from 27 to $50{ }^{\circ} \mathrm{C}$ (FAO 2008). These countries also have a large space of the deserts. The desert temperatures range from 45 to $60{ }^{\circ} \mathrm{C}$ in summer and from 7 to $35^{\circ} \mathrm{C}$ in the winter and the sunlight intensity ranges from 5.2 to $6.8 \mathrm{kWh} / \mathrm{m}^{2} /$ day (Al-Ashwal and Basalah 2012). Therefore, one of the proposals to reduce the environment pollution by sewage generated from STPs is by extending the sewerage network to the desert. The desert provides many of the features of SODIS necessary to treat the sewage effluents such as the large areas and the temperature and the treated sewage could be used in the land reclamation.

\section{Reduction of pathogenic bacteria in biosolids}

Sewage treatment processes can be classified as primary and secondary processes. In primary treatment, solids are mainly removed mechanically from untreated sewage. Secondary treatment is a biological process in which decomposers are utilized to remove biodegradable pollutants. Decomposers are organisms such bacteria and fungi that get energy and nutrients by digesting waste matter in the sewage. In the activated sludge process, sewage is pumped into a large tank where aerobic microorganisms decompose the organic matter (WHO 2002). Chemical treatment is sometimes used and it encourages small particles and dissolved substances to form large particles which facilitate separation. This is called chemical precipitation. Sludge is formed when these larger particles clump together during suitable separation methods (Casey 1997).

All the sludge that is separated during these treatment methods (mechanical, biological and chemical) is defined as a raw sludge, which has to undergo various kinds of further treatment for the improving the microbiological quality and then for safe disposal or reuse. Physical, chemical and biological processes accomplish the stabilization and disinfection of sewage sludge. Stabilization refers to those processes that reduce the volatile solids content, pathogen levels and odour. The biosolids generated from sewage treatment processes must be subject to further treatment to reduce pathogenic bacteria which are still high in concentrations even after the treatment processes (Al-Gheethi et al. 2014). Disinfection processes emphasize the reduction of pathogenic bacteria below detectable limits. Major stabilization methods include anaerobic digestion, aerobic digestion, composting, alkaline (lime) stabilization and air-drying. Disinfection includes pasteurization, long-term storage, irradiation, heat drying and heat treatment (US EPA 2003).

According to US EPA, there are two processes are used to the reduction of pathogenic bacteria to comply the standards limits of biosolids (Class A and B). These processes named Processes to Further Reduce Pathogens (PFRPs, Table 3) and Processes to Significantly Reduce Pathogens (PSRPs, Table 4). The details of the most common treatment processes are described below.

Table 3 Processes to Further Reduce Pathogens (PFRPs). Source; US EPA (2003)

\begin{tabular}{|c|c|}
\hline Treatment process & Procedure of the treatment process \\
\hline Composting & $\begin{array}{l}\text { Using either the within-vessel composting method or the static aerated pile composting method, the tempera- } \\
\text { ture of sewage sludge is maintained at } 55{ }^{\circ} \mathrm{C} \text { or higher for } 3 \text { consecutive days. Using the windrow composting } \\
\text { method, the temperature of the sewage sludge is maintained at } 55{ }^{\circ} \mathrm{C} \text { or higher for } 15 \text { consecutive days or } \\
\text { longer. During the period when the compost is maintained at } 55^{\circ} \mathrm{C} \text { or higher, there shall be a minimum of } \\
\text { five turnings of the windrow }\end{array}$ \\
\hline Heat drying & $\begin{array}{l}\text { Sewage sludge is dried by direct or indirect contact with hot gases to reduce the moisture content of the sewage } \\
\text { sludge to } 10 \% \text { or lower. Either the temperature of the sewage sludge particles exceeds } 80{ }^{\circ} \mathrm{C} \text { or the wet bulb } \\
\text { temperature of the gas in contact with the sewage sludge as the sewage sludge leaves the dryer exceeds } 80{ }^{\circ} \mathrm{C}\end{array}$ \\
\hline Heat treatment & Liquid sewage sludge is heated to a temperature of $180^{\circ} \mathrm{C}$ or higher for $30 \mathrm{~min}$ \\
\hline Thermophilic aerobic digestion & $\begin{array}{l}\text { Liquid sewage sludge is agitated with air or oxygen to maintain aerobic conditions and the mean cell residence } \\
\text { time (i.e., the solids retention time) of the sewage sludge is } 10 \text { days at } 55-60^{\circ} \mathrm{C}\end{array}$ \\
\hline Beta ray irradiation & $\begin{array}{l}\text { Sewage sludge is irradiated with beta rays from an electron accelerator at dosages of at least } 1.0 \text { megarad at } \\
\text { room temperature }\left(\text { ca. } 20^{\circ} \mathrm{C}\right)\end{array}$ \\
\hline Gamma-ray irradiation & $\begin{array}{l}\text { Sewage sludge is irradiated with gamma rays from certain isotopes, such as Cobalt } 60 \text { and Cesium } 137 \text {, at dos- } \\
\left.\text { ages of at least } 1.0 \text { megarad at room temperature (ca. } 20^{\circ} \mathrm{C}\right)\end{array}$ \\
\hline Pasteurization & The temperature of the sewage sludge is maintained at $70^{\circ} \mathrm{C}$ or higher for $30 \mathrm{~min}$ or longer \\
\hline
\end{tabular}


Table 4 Processes to significantly reduce pathogens (PSRPs). Source; US EPA (2003)

\begin{tabular}{|c|c|}
\hline Treatment process & Procedure of the treatment process \\
\hline Composting & $\begin{array}{l}\text { Using either the within-vessel, static aerated pile, or windrow composting methods, the temperature of the sewage sludge } \\
\text { is raised to } 40{ }^{\circ} \mathrm{C}\left(104{ }^{\circ} \mathrm{F}\right) \text { or higher and remains at } 40^{\circ} \mathrm{C} \text { or higher for } 5 \text { days. For } 4 \text { h during the } 5 \text { day period, the } \\
\text { temperature in the compost pile exceeds } 55^{\circ} \mathrm{C}\end{array}$ \\
\hline Aerobic digestion & $\begin{array}{l}\text { Sewage sludge is agitated with air or oxygen to maintain aerobic conditions for a specific mean cell residence time } \\
\text { (i.e., solids retention time) at a specific temperature. Values for the mean cell residence time and temperature shall be } \\
\text { between } 40 \text { days at } 20^{\circ} \mathrm{C} \text { and } 60 \text { days at } 15^{\circ} \mathrm{C}\end{array}$ \\
\hline Air drying & $\begin{array}{l}\text { Sewage sludge is dried on sand beds or on paved or unpaved basins. The sewage sludge dries for a minimum of } 3 \text { months. } \\
\text { During } 2 \text { of the } 3 \text { months, the ambient average daily temperature is above } 0{ }^{\circ} \mathrm{C}\end{array}$ \\
\hline Anaerobic digestion & $\begin{array}{l}\text { Sewage sludge is treated in the absence of air for a specific mean cell residence time (i.e., solids retention time) at a } \\
\text { specific temperature. Values for the mean cell residence time and temperature shall be between } 15 \text { days at } 35-55^{\circ} \mathrm{C} \text { and } \\
60 \text { days at } 20^{\circ} \mathrm{C}\end{array}$ \\
\hline Lime stabilization & Sufficient lime is added to the sewage sludge to raise the $\mathrm{pH}$ of the sewage sludge to 12 for $\geq 2 \mathrm{~h}$ of contact \\
\hline
\end{tabular}

\section{Anaerobic digestion}

Anaerobic digestion is a biological process that uses bacteria that function in an oxygen-free environment to convert volatile solids into carbon dioxide, methane and ammonia. Those reactions take place in an enclosed tank that may or may not be heated, because the biological activity consumes most of the volatile solids needed for further bacterial growth (US EPA 2003). The mesophilic anaerobic digestion (MAD) of biosolids has been reported to produce biosolids Class B, this treatment process is common in USA (Wong et al. 2010). However, most Middle East countries used air-drying as will be presented below (Sect. "Air drying").

Telles et al. (2002) investigated the reduction of TC, FC, $P$. aeruginosa and FS by anaerobic digestion of sewage sludge generated from STP in Maringá-Paraná, Brazil. The study showed that $99.9 \%$ of FS, $96.3 \%$ of TC and $95 \%$ of $P$. aeruginosa were reduced at the end of the treatment process. These findings revealed the potential of anaerobic digestion in the reduction of pathogenic bacteria from the biosolids. Wakelin et al. (2003) showed that FC was reduced from $7.5 \log _{10} \mathrm{CFU} \mathrm{g}^{-1}$ in the raw sewage to $6.3 \log _{10} \mathrm{CFU} \mathrm{g}{ }^{-1}$ in dewatered biosolids after mesophilic anaerobic digestion process. The main pathogen-reducing factor during thermophilic anaerobic digestion is temperature in relation to time, while the competition among microorganisms for nutrients is the limiting factor that reduces pathogen amounts in anaerobic mesophilic treatment of biosolids (Smith et al. 2005). It can be noted that the thermophilic treatment is more efficient than the mesophilic because the biosolids have high contents of nutrients; therefore, the competition between microorganisms in the biosolids is weak. Carrington (1998) also elucidated that temperature is not the main factor in mesophilic anaerobic digestion processes at $35^{\circ} \mathrm{C}$, but this process produces fatty acids and other products that are lethal to many pathogenic bacteria.
Ziemba and Peccia (2011) evaluated mesophilic, thermophilic, temperature-phase, and high-temperature (60 or $70{ }^{\circ} \mathrm{C}$ ) batch pre-treatment digester configurations for $E$. coli and $E$. faecalis inactivation potential. The results revealed that the inactivation rates have increased dramatically at temperatures above $55^{\circ} \mathrm{C}$. In mesophilic treatment, 1-2 log inactivation was recorded, while was $2-5 \log$ inactivation at $50-55^{\circ} \mathrm{C}$ in thermophilic and temperature-phase treatments. Incorporating a 60 or $70{ }^{\circ} \mathrm{C}$ batch pre-treatment phase has achieved completed inactivation (over $100 \log$ reductions) of E. coli and E. faecalis.

Chen et al. (2012) investigated inactivation of Salmonella sp. E. coli and Shigella sp. during mesophilic anaerobic digestion of biosolids. They found that the anaerobic digestion process efficiency reduces Salmonella sp. and $E$. coli during the retention time from 11 to 25 day. However, the reduction of Shigella sp. was insignificant. However, the long period of the treatment process ( 25 days) might lead to increase the overload of the STP and thus required high capacity to store the received sewage before the treatment process. Astals et al. (2012) studied the mesophilic anaerobic digestion, thermophilic anaerobic digestion and mesophilic anaerobic digestion followed by a $60{ }^{\circ} \mathrm{C}$ or by an $80^{\circ} \mathrm{C}$ hygienization treatment of sewage sludge. They recorded that both thermophilic anaerobic digestion and mesophilic anaerobic digestion followed by a hygienization step reduced $E$. coli to meet the standards limits recommended by US EPA and the European legislation for land application.

According to aforementioned studies, the anaerobic digestion process of biosolids showed potential for effective reduction of pathogenic bacteria to meet the standards limits recommended by US EPA. However, Viau and Peccia (2009) detected Legionella pneumophila, S. aureus and $C$. difficile in biosolids generated from 29 STPs in USA which was treated with mesophilic, temperaturephase anaerobic digestion and composting process, which

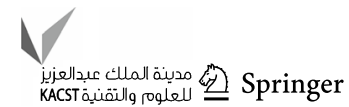


indicates to the ability of some pathogenic bacteria to survive in the biosolids even after the thermophilic treatment. This might be due to the presence solids materials which might protect the bacterial cells form the temperature actions. Chen et al. (2011) indicated that the pathogenic bacteria in the treated biosolids could regrow again during the storage periods of biosolids. This is due to the microbial response to substrate release and environmental changes, such as oxygen, which favour the bacterial regrowth during 1-2 weeks of storage period.

\section{Aerobic digestion}

In aerobic digestion, biosolids are biochemically oxidized by bacteria in an open or enclosed vessel. Under proper operating conditions, the volatile solids in biosolids are converted to $\mathrm{CO}_{2}$ and $\mathrm{H}_{2} \mathrm{O}$ (US EPA 2003). The PSRPs described aerobic digestion as follows: Sewage sludge is agitated with oxygen to maintain aerobic condition for indigenous cell. Time and temperature shall be between 40 days at $20^{\circ} \mathrm{C}$ and 60 days at $15{ }^{\circ} \mathrm{C}$. Aerobic digestion carried out according to the part 503 requirement typically reduces pathogenic bacteria by $2 \log$ (US EPA 2004a). Kabrick and Jewell (1982) found that Salmonella spp. was reduced to undetectable levels in an aerobic reactor at $35^{\circ} \mathrm{C}$ in $24 \mathrm{~h}$, while at $60{ }^{\circ} \mathrm{C}$ Salmonella spp. was eliminated in few hours.

Han et al. (2011) studied the efficiency of anaerobic lagoon fermentation (ALF) and autothermal thermophilic aerobic digestion (ATAD) for removal of pathogenic bacteria in raw swine manure. The results revealed that in raw swine manure, Dialister pneumosintes, Erysipelothrix rhusiopathiae, Succinivibrioan dextrinosolvens, and Schineria sp. were detected. ATAD exhibited more efficiency to eliminate of these pathogens than ALT. In the mesophilic ALF-treated swine manure, Schineria sp. and Succinivibrio dextrinosolvens were still detected, while were undetected in ATAD. These findings support the superiority of ATAD in selectively reducing potential human and animal pathogens compared to ALF, which is a typical manure stabilization method used in livestock farms. In a comparison between aerobic and anaerobic treatment of biosolids, it can be indicated that the anaerobic process is more efficient than the aerobic process, but the limitations to apply the anaerobic treatment lie in the design and the maintenance in the developing countries.

\section{Air-drying}

Air-drying allows partially digested biosolids to dry naturally in the open air. Wet biosolids are usually applied to a depth of approximately $23 \mathrm{~cm}$ onto sand drying beds or even deeper (US EPA 2000). The sewage sludge is left to dry by the evaporation. The effectiveness of the air-drying process depends very much on the local climate. Drying occurs faster and more completely in warm and dry weather and slower and less completely in cold and wet weather. The density of pathogenic bacteria is reduced by approximately $2 \log$ under these conditions of air drying. However, this reduction is not enough to produce high quality of biosolids for safe disposal. More disadvantage of air drying is the deficiency in the produce biosolids with only $38 \%$ volatile solids destruction (US EPA 2003).

Ward et al. (1981) studied the response of Klebsiella, Enterobacter, Proteus mirabilis, S. typhimurium, E. coli and $S$. faecalis to the moisture loss through evaporation at $21{ }^{\circ} \mathrm{C}$. In raw sterilized sludge with $5 \%$ solids, seeded enteric bacteria initially increased in concentration with dewatering. This increase was always followed by a consistent decrease in numbers with further dewatering, especially below $50 \%$ moisture. A 1-2 log reduction was seen for all bacterial strains except Proteus sp. which showed a $4 \log$ reduction within 7 days as biosolids percent solids increased to $95 \%$. Rouch et al. (2011) examined the inactivation of E. coli and $C$. perfringens during the air-drying of anaerobically digested biosolids generated from two STPs in Victoria, Australia. The results found that $E$. coli were reduced to below $10^{2} \mathrm{CFU} \mathrm{g}^{-1}$ dry solids after drying of 8-15 days and the biosolids met US EPA standards for Class A. C. perfringens appeared to be a better indicator.

Air-drying of biosolids is common in Middle East countries because the climate is semi-arid to arid and the temperatures range from 27 to $50{ }^{\circ} \mathrm{C}$ (FAO 2008). Besides, this process is not expensive and easily implementable. However, one of the major disadvantages of this process is the vector attractions, which increase as result to volatile solids in the biosolids. The pathogens are transmitted from air-drying basin by the vectors to animals and human (Palmgren 2002). STPs in Yemen overcame this problem by using pesticide but this method leads to accumulate of pesticide in the lands during land application of biosolids. To overcome the vector attraction, US EPA recommended that the reduction of VS $\%$ should be more than $38 \%$. The lime stabilization was reported to achieve these standards as will be presented in section 10.6. Another way to prevent the vector attraction is by covering the air-drying basin by transparent polyethylene terephthalate (PET) as in the case of SODIS of water and wastewater. However, more research is needed in this regards.

\section{Effect of storage}

Biosolids are stored inside buildings and outside enclosed in steel or concrete tanks. The storage duration of biosolids could strongly affect the survival of pathogenic bacteria. During storage, the biosolids undergo biochemical changes, which depend on the storage temperature. These 
changes effect on the survival of pathogenic bacteria. The storage of biosolids at low temperatures prolong pathogens survival, while at high storage temperatures free ammonia which would shorten the pathogens chances for survival is produced (Svoboda and Carcluie 2003).

Ahmed and Sorensen (1995) evaluated pathogen inactivation during storage of biosolids. The pathogens tested included S. typhimurium, Y. enterocolitica, Campylobacter jejuni. Biosolids samples seeded with the pathogens were incubated under both anaerobic and aerobic conditions in reactors at $5,22,38$ and $49.5{ }^{\circ} \mathrm{C}$ for up to 62 days. They revealed that pathogenic bacteria decreased in stored biosolids at all temperatures and survival decreased as the temperature increased.

Liu (2000) observed that FC in biosolids was inactivated naturally by storing the sample in an airtight container at room temperature $\left(20-23{ }^{\circ} \mathrm{C}\right)$. This natural inactivation started after 17-28 days of storage and FC were not detected after 100 days of storage. However, FC density in samples stored at -22 and $4{ }^{\circ} \mathrm{C}$ had no significant reduction in 3 months. Nicholson et al. (2000) recorded that slight increases in temperature during summer destroy E. coli O157 and radically decrease number of Salmonella after a few months.

Placha et al. (2001) found that in pig slurry, S. typhimurium survived for 26 days in summer and 85 days in winter and $\mathrm{FC}$ were reduced by $90 \%$ in 35 and 233 days during summer and winter time, respectively. However, storage alone is not regarded as an effective way to inactivate pathogens in sludge (Carrington 1998). Avery et al. (2005) monitored the decline in E. coli $\mathrm{O} 157$ in different wastes over 64 days. They concluded that the storage decreases the amount of E. coli $\mathrm{O} 157$ but does not eliminate the pathogen. According to Sahlstrom et al. (2006), the sludge is stored usually for 6 months, in heaps outdoors on the ground or on a concrete surface, before being used. After 2 months of storage of sewage sludge, no Salmonella spp. could be isolated in the heaped material. Al-Gheethi et al. (2014) observed that the biosolids stored for 24 weeks at room temperature $\left(25 \pm 2{ }^{\circ} \mathrm{C}\right)$ met the standards limits recommended by US EPA, Class A, and suitable for reuse in the agriculture as fertilizers.

\section{Heat treatments}

Heat drying involves using active or passive dryers to destroy pathogens and remove water from biosolids. In this process, biosolids are dried with hot gases at temperatures greater than $80{ }^{\circ} \mathrm{C}$ to reduce the moisture content to $10 \%$ or lower. Pathogenic bacteria, viruses, and helminth ova are reduced to below detectable levels in properly operated heatdrying systems (Lucero-Ramirez 2000). Pathogenic bacteria are inactivated during exposure to heat, above their optimum growth temperature. The period of exposure is depended on the temperature as well as the bacterial species (Himathongkham and Riemann 1999).

The total inactivation of pathogenic bacteria in biosolids requires a holding time of $4.78 \mathrm{~h}$ at $60{ }^{\circ} \mathrm{C}$ compared to $30 \mathrm{~min}$ at $70{ }^{\circ} \mathrm{C}$ (US EPA 1994). Moce-Llivina et al. (2003) recorded significant reductions in indigenous $E$. coli to below detectable levels after 30 and $90 \mathrm{~min}$ at $80^{\circ} \mathrm{C}$. The indigenous FS was only reduced between 1.4 and $1.8 \log _{10}$ units after $30 \mathrm{~min}$ but undetectable after $90 \mathrm{~min}$. S. choleraesuis cells that were added to sludge at high counts were reduced by approximately $6 \log _{10}$ after $30 \mathrm{~min}$ at $80^{\circ} \mathrm{C}$ and by more than $8 \log _{10}$ after $60 \mathrm{~min}$ at $80^{\circ} \mathrm{C}$. They concluded that temperature of $80{ }^{\circ} \mathrm{C}$ for $30-60$ min would probably qualify the biosolids product as Class A requirements.

The EPA Part 503 regulations consider heat drying as PFRPs and suggest that, the temperature of the biosolids should exceed $80^{\circ} \mathrm{C}$ but no time is given treatment period. In other instances, it seems clear that processes using higher than $60-70{ }^{\circ} \mathrm{C}$ can produce biosolids Class A (Springthorpe and Sattar 2004).

Abdel-Monem et al. (2008a) investigated the inactivation of TC, FC, FS and Salmonella spp. in biosolids by thermal treatment at 60 and $80^{\circ} \mathrm{C}$. The study revealed that the inactivation of Salmonella spp. and FS was significantly greater than the inactivation of TC at $80{ }^{\circ} \mathrm{C}$ for $90 \mathrm{~min}$. After heat treatment at $80{ }^{\circ} \mathrm{C}$ for $120 \mathrm{~min}$, TC reduced by $5.5 \log _{10}$ while FC, FS and Salmonella were undetected and the biosolids met the US EPA, Class A standards for biosolids reuse.

\section{Lime stabilization treatments}

The principle objectives of alkaline stabilization are to reduce the activity of pathogenic bacteria and inhibit their regrowth and thus reduce the health hazard associated with the biosolids (WEF 1995). The most commonly used alkaline is the quick lime (calcium oxide, $\mathrm{CaO}$ ) and its derivative hydrated lime or slaked lime (calcium hydroxide, $\mathrm{Ca}(\mathrm{OH})_{2}$ ) which are used due to their low cost. Adding adequate volume of $\mathrm{CaO}$ to the biosolids leads to increase of $\mathrm{pH}$ to 12 (or higher) and temperature to be between 55 and $70{ }^{\circ} \mathrm{C}$, and as results for these conditions the pathogenic bacteria are inactivated or destroyed (Hansen et al. 2007).

Plachy et al. (1996) demonstrated that S. typhimurium was eliminated from biosolids after $60 \mathrm{~min}$ of hydrated lime addition. Reimers (1997) found that the inactivation of pathogenic bacteria by lime was not only because of the hydroxide ions but also because of silicate components in lime. This conclusion was derived from studies by comparing pathogen inactivation effects of sodium hydroxide and calcium hydroxide. According to Schwartzbrod et al. (1997) the raising of the $\mathrm{pH}$ to at least $\mathrm{pH} 12$ by the use of lime has

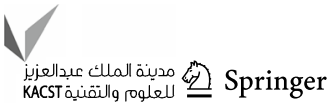


the effect to suspend microbiological activity and lime conditioning in specific conditions ( $\mathrm{pH}$ of 12.5 for 2-4 months) can cause helminths reduction by $98.5 \%$ and a virus inactivation by $90 \%$, while biosolids met the Class B requirements when the $\mathrm{pH}$ was 12 or above after $2 \mathrm{~h}$ of contact.

Amer (1997) studied the effect of quick lime $(\mathrm{CaO})$ and cement dust additions to biosolids on the reduction of pathogenic bacteria. Rapid reduction in TC, Salmonella and Shigella counts were achieved after the addition of quick lime and cement dust. US EPA (2000) reported that biosolids Class A requirements can be achieved when the $\mathrm{pH}$ of the mixture is maintained at or above 12 for at least $72 \mathrm{~h}$, with a temperature of $52{ }^{\circ} \mathrm{C}$ maintained for at least $12 \mathrm{~h}$ during the period.

Bina et al. (2004) investigated the effect of liming on the microbiological quality of urban liquid raw biosolids. The lime was added to increase the $\mathrm{pH}$ of biosolids to $\mathrm{pH}$ 11 and 12 for 2, 24, 72 and 120 h. Salmonella spp. were inactivated completely in treated biosolids after $2 \mathrm{~h} .99 \%$ of $\mathrm{FC}$ reduction was obtained for two ranges of $\mathrm{pH}(\mathrm{pH} 11$ and 12). Biosolids treated with lime met US EPA standards for Class B and Class A after 2 and $24 \mathrm{~h}$, respectively. At $\mathrm{pH}$ higher than $\mathrm{pH} 11$ and 12 treated biosolids with lime met vector attraction reduction requirements after $2 \mathrm{~h}$

Sasdkovd et al. (2005) stored biosolids amended with zeolite and lime for 42 days at a temperature between 14.5 and $17.9{ }^{\circ} \mathrm{C}$. Samples were taken at 5-day intervals for the determination of TC, FC and FS. The results revealed a decrease in plate counts of the observed bacteria in experimental substrates compared to the control biosolids. Yurtsever (2005) found that about $150-200 \mathrm{~g} \mathrm{CaO} \mathrm{kg}^{-1}$ TS is satisfactory for keeping $\mathrm{pH}$ on recommended levels and to reduce $\mathrm{FC}$ to less than detectable limits.

In alkaline treatment study conducted by AbdelMonem et al. (2008b), the results revealed that $19.12 \mathrm{~g}$ of quicklime $\mathrm{kg}^{-1}$ TS reduced $\mathrm{FC}$ to meet the requirements of US EPA standards for Class B after $2 \mathrm{~h}$ and Class A criteria after $24 \mathrm{~h}$. Salmonella spp. reduced to meet Class A criteria after $120 \mathrm{~h}$. At $29.41 \mathrm{~g} \mathrm{~kg}^{-1} \mathrm{TS}, \mathrm{FC}$ and Salmonella spp. dropped to below US EPA Class A limit after $24 \mathrm{~h}$. At $42.65 \mathrm{~g} \mathrm{~kg}^{-1} \mathrm{TS}$, FC has reduced to below detection level after $24 \mathrm{~h}$ and Salmonella after $2 \mathrm{~h}$. US EPA requirements for Class B met after $2 \mathrm{~h}$, while the requirements for Class A met for Salmonella spp. after $2 \mathrm{~h}$ and FC after $24 \mathrm{~h}$. Finally, $133.52 \mathrm{~g} \mathrm{~kg}^{-1} \mathrm{TS}$ of lime was found to be very effective, Salmonella spp. and FC were inactivated completely after $2 \mathrm{~h}$. To reduce vector attraction, US EPA recommended that the reduction of VS $\%$ should be more than $38 \%$ (US EPA 2003). In the study conducted by Al-Gheethi (2008), the mass of volatile solids in the biosolids has reduced by $63.47 \%$ with
$42.65 \mathrm{~g} \mathrm{~kg}^{-1}$ TS and $91.41 \%$ with $133.52 \mathrm{~g} \mathrm{~kg}^{-1}$ after $120 \mathrm{~h}$.

Toth et al. (2012) investigated the alkaline treatment of animal manures by hydrated lime $\left(\mathrm{CaOH}_{2}\right)$ to eliminate S. enterica and E. coli $\mathrm{O} 157: \mathrm{H} 7$. They found that both pathogens were killed when $\mathrm{pH}$ was more than 11.0 within 2 weeks. Farzadkia and Bazrafshan (2014) studied the lime stabilization of biosolids on the inactivation of FC. The study was conducted in a reactor for 6 weeks, the biosolids stabilization with hydrated lime reduced FC more than 99.99\% and the stabilized biosolids met US EPA standards limits of class B.

\section{Pathogen growth potential (PGP)}

PGP is defined as the ability of inactivated bacteria to regrow again in the disinfected sample. The effectiveness of disinfection process for treated sewage and biosolids depends on inactivation of pathogenic bacteria. However, it is well known that under unfavourable conditions, bacteria may transfer into a dormant state called viable but non-culturable (VBNC), which mean the microorganism has slow metabolic processes and no cell division (Oliver 2005). Therefore, the development of the detection, enumeration and viability assessment of pathogenic bacteria in biosolids is required (Sidhu and Toze 2009). For microbial cell, death is the irreversible loss of microbial cell to growth and reproduction. To verify this fact the isolation on solid culture medium is the suitable method. The microbial cell is considered dead if they fail to form colonies. However, the cultural based technique depends on culture medium used. Bacteria may fail to grow on solid media and need to be cultured first in enrichment media (Block 2001; Efaq et al. 2015).

The condition of storage for disinfected sample affect the ability of bacteria to regrow, for example, bacterial inactivation by UV irradiation may reach to $99.99 \%$, but if the disinfected sample stored at optimal conditions the regrowth of inactivated bacteria may reach to $90 \%$. This means the bacteria can repair damage caused by UV. AlGheethi et al. (2013b) found that Salmonella spp. S. aureus and E. faecalis grow again in treated sewage exposed to SODIS for $6 \mathrm{~h}$, when the samples were incubated at $37{ }^{\circ} \mathrm{C}$ for 4 days. The bacterial regrowth may occur if the treatment process did not lead to physical damage of bacterial cell and PGP bioassay should be carried out (Al-Gheethi et al. 2016a, b; Efaq et al. 2017). PGP has been used to assay bacterial growth in drinking water disinfected by ozonation and different bio-filter systems (Berney et al. 2006; Vital et al. 2010).

Choi et al. (1999) stated that the main factors, which convert dormant bacteria cell to be active, the factors 
included the incubation and substrate addition such as glucose, amino acids or yeast extract. Luna et al. (2002) found that after nutrient enrichment, a large fraction of dormant bacteria (6-11\% of the inactivated bacterial number) was reactivated.

The factors, which might induce bacterial cell to be VBNC, are less nutrients, nucleotide, inactive cell membrane, size of bacterial cells and presence of antibiotics, which inhibit DNA synthesis without affecting other cellular metabolic activities (Gasoll et al. 1995; Joux and LeBaron 1997; Luna et al. 2002; Kim et al. 2009). Therefore, some authors recommended using molecular techniques such as PCR to detect the presence of VBNC bacteria after disinfection process (Straub et al. 1993; Choi et al. 1996). Chen et al. (2012) determined log reduction of Salmonella sp., E. coli and Shigella sp. during mesophilic anaerobic digestion of sludge by MPN and PCR. They found that log reduction determined by MPN was much higher than the data recorded by quantitative PCR. They explained their findings due to the presence of viable but non-culturable pathogen cells.

However, other investigators reported that PCR technique is not suitable after disinfection process as PCR can still recognize or detect the DNA fragments of the bacterial cells that have been killed during disinfection processes, thus, yielding false positive results (Baloda and Krovacek 1994). Fijalkowski et al. (2014) detected the presence of E. coli O157:H7 in wastewater and sewage sludge in Poland by quantitation method of (EMA) real time-PCR. They found that $E$. coli $\mathrm{O} 157: \mathrm{H} 7$ gene copies were detected in primary influents and final effluents in winter from municipal wastewater treatment plant. However, the ethidium monoazide bromide (EMA) application revealed false-positive detection of this bacterium in final effluents. They also detected large amount of "free DNA" derived from dead cells that gave false-positive results.

In the last decades, authors have detected the viability of bacterial cells based on metabolic activity, such as detection of RNA transcripts, a positive energy status and responsiveness. The detected RNA transcripts were used to detect viable cells in combination with DNA amplification techniques. The technology depends on the treatment of bacterial cells with photoactivatable, and cell membrane impermeant with nucleic acid intercalating dyes propidium monoazide (PMA) or ethidium monoazide (EMA) followed by light exposure prior to extraction of DNA and amplification. Light activation of DNA-bound dye molecules results in irreversible DNA modification and subsequent inhibition of its amplification. Sample pre-treatment with viability dyes has been used in combination with PCR (leading to the term viability PCR, v-PCR), and increasingly with isothermal amplification method (Fittipaldi et al. 2012). This technique still has some limitations especially when applied to environmental samples.

Some researchers used the culture method and the molecular analysis to investigate the presence of pathogenic bacteria in the VBNC state. Jiang et al. (2013) combined the standards culture method (MPN technique) with the reverse transcription quantitative PCR (RT-qPCR) assay for the quantification of $S$. typhimurium, E. coli and $S$, flexneri in the VBNC state during anaerobic digestion of biosolids. They revealed that the cycle threshold $\left(C_{\mathrm{T}}\right)$ values from RTqPCR assays have significant correlation to the counts of E. coli $\left(R^{2}=0.9964\right)$, S. typhimurium $\left(R^{2}=0.9938\right)$ and $S$. flexneri $\left(R^{2}=0.997\right)$. In addition, they stated that the quantification results of VBNC pathogens using RT-qPCR could provide an improved evaluation of pathogen inactivation efficiency and biological safety in the biosolids.

Real-time quantitative polymerase chain reaction (qPCR) is fast, sensitive, and specific molecular tool for enumeration of pathogens in biosolids. However, the main limitation is that it amplifies all target DNAs, including that from non-viable cells. Therefore, to overcome this limitation the authors suggested that the couple qPCR with PMA (van Frankenhuyzen et al. 2011) or EMA (Fijalkowski et al. 2014) can be used to monitor the presence of viable pathogens in several different matrices.

\section{Current status of sewage treatment in Middle East countries}

In the Middle East countries, there is no plan to build tertiary treatment systems (except some STPs in Riyadh, Saudi Arabia which use sand filters as a tertiary treatment process, Al-Jasser 2011). They focus on the basic standard of primary and secondary treatment. Most sewage is reused for agricultural irrigation purpose. This is due to increase in population growth rate, besides present expansion of water networks in these countries without parallel construction of new sewage network, or rehabilitation of the existing ones (Abdel-Raouf et al. 2012).

Most treated sewage and biosolids generated from STPs in Middle East countries have not met the standards limits required by WHO and US EPA. Saleem et al. (2001) investigated the counts FC during summer and winter seasons in the drying biosolids generated from Al-Khobar sewage treatment plant in Saudi Arabia. They found that FC was more than standards limits required for US EPA, Class B. El-Lathy et al. (2009) reported that the concentrations of Salmonella spp., in biosolids generated from Zenin sewage treatment plant at Giza Governorate, Egypt were $330 \mathrm{CFU} / \mathrm{mL}$, which means the biosolids, has not met the standards limits recommended by US EPA for biosolids Class A. AL-Jaboobi et al. (2013) stated that FC in the treated sewage canal generated 
from STP (primary and secondary processes) located in Sana' a Yemen was more than WHO guidelines. Al-Gheethi et al. (2014) evaluated the efficiency of five STPs in Yemen for reduction of faecal indicators and pathogenic bacteria in the secondary effluents and biosolids. They also found that FC was more than WHO guidelines for sewage effluents as well as US EPA Class A, and B for biosolids.

In comparison to developed countries, Rose et al. (2004) investigated the efficiency of six STPs in USA for reduction of FC. All STPs used primary treatment, four STPs used the biological treatment (activated sludge), one STP used nitrification and one STP used biological nutrient removal. Filtration process is carried out by fabric, sand and anthracite. Disinfection process is carried out by chlorine, sodium hypochlorite and UV irradiation. However, the concentrations of FC in treated sewage at six STPs were more than the WHO guidelines. In the light of the aforementioned, Enerhall and Stenmark (2012) also reported that TC and enterococci were 5.8 and $5.08 \log _{10}$ CFU/100 mL, respectively in treated sewage generated from STP in Sweden, which used filtration system during the disinfection process. Viau and Peccia (2009) stated that the concentrations of FC in biosolids generated from 29 STPs in USA, which use mesophilic anaerobic digestion (MAD), temperature-phased anaerobic digestion (TPAD), composting the biosolids after anaerobic digestion (COM) corresponded to US EPA regulatory limits for each biosolids Class A and Class B.

\section{Conclusion}

The reuse of sewage-treated effluent and biosolids for agricultural purpose has increased extensively in the last few decades in the Middle East countries. Those countries face a severe shortage of water resources and tertiary sewage treatment plants are not available. Treated sewage and biosolids are rich with nitrogen and phosphate that would improve plant growth and soil properties. However, it has also a large diversity of pathogenic bacteria, which represent a potential risk for human and animal. Most of these pathogens could survive for a long time in the environment, because these pathogens produce endospores and others can survive in VBNC state. Therefore, further treatment of sewage effluents and biosolids generated from secondary treatment is necessary to reduce the pathogenic bacteria before reuse for agricultural purpose. Further treatment using technologies such as SODIS, air-drying and lime treatment appears to be more suitable to the nature and climate of Middle East countries and can vouch for their efficiencies. These processes have the potential to reduce pathogenic bacteria in treated sewage and biosolids. Economically, the processes are efficient, easily implementable, natural, with no toxic by-products and most of all are of low cost.

Open Access This article is distributed under the terms of the Creative Commons Attribution 4.0 International License (http://creativeco mmons.org/licenses/by/4.0/), which permits unrestricted use, distribution, and reproduction in any medium, provided you give appropriate credit to the original author(s) and the source, provide a link to the Creative Commons license, and indicate if changes were made.

\section{References}

Abdel-Monem MO, Al-Zubeiry AH, AL-Gheethi AAS (2008a) Survival of enteric indicators and pathogenic bacteria in sewage sludge after thermal treatment. J Botany 27(1):171-183

Abdel-Monem MO, Al-Zubeiry AH, AL-Gheethi AAS (2008b) Elimination of Salmonella and faecal indicator bacteria in sewage sludge by quick lime stabilization. J Environ Sci 36:281-297

Abdel-Raouf N, Al-Homaidan AA, Ibraheem IBM (2012) Microalgae and wastewater treatment. Saudi J Biol Sci 19(3):257-275

Acra A, Jurdi H, Mu' allem Y, Karahagopian Y, Raffoul Z (1990) Water disinfection by solar radiation: assessment and application. International Development Research Centre (IDRC), Ottawa

ACWUA (2010) Wastewater reuse in Arab Countries, working group on wastewater reuse. Arab Countries Water Utility Association (ACEUA), Amman

Ahmed AU, Sorensen DL (1995) Kinetics of pathogen destruction during storage of dewatered biosolids. Water Environ Res 67(2): $143-150$

Aksu Z, Tunc O (2005) Application of biosorption for penicillin G removal: comparison with activated carbon. Process Biochem 40(2):831-847

Alamanos Y, Maipa V, Levidiotou S, Gessouli E (2000) A community waterborne outbreak of gastro-enteritis attributed to Shigella sonnei. J Epidemiol Infect 125(3):499-503

Al-Asbahi QY (2005) Water resources information in Yemen. IWGEnvironmental International Work Session on Water Statistics, Vienna

Al-Ashwal AM, Basalah AO (2012) Energy conservation indicators in Southern Mediterranean countries. Country report for Yemen. Plan Bleu UNEP/MAP Regional Activity Centre, Sophia Antipolis

Alcalde L, Oron G, Gillerman L, Salgot M, Manor Y (2003) Removal of faecal coliforms, somatic coliphages and F-specific bacteriophages in a stabilization pond and reservoir system in arid regions. Water Sci Technol 3(4):177-184

Al-Enezi G, Hamoda MF, Fawzi N (2004) Heavy metals content of municipal wastewater and sludges in Kuwait. J Environ Sci 39(2):397-407

Al-Gheethi AAS (2008) Bacteriological studies on sludge from some municipals wastewater treatment plants in Yemen. MS.c Thesis, Department of Applied Microbiology, Faculty of Applied Science, Taiz University, Taiz, Yemen

Al-Gheethi AAS (2014) Screening of bacterial isolates from sewage treated effluent with potential to remove heavy metals and $\beta$-lactam antibiotics. Ph.D. Thesis, Environmental Technology Division, School of Industrial Technology, University Science Malaysia. Penang, Malaysia

Al-Gheethi AAS, Ismail N (2014) Biodegradation of pharmaceutical wastes in treated sewage effluents by Bacillus subtilis 1556WTNC. Environ Process 1(4):459-489 
Al-Gheethi AAS, Norli I, Kadir MO (2013a) Elimination of enteric indicators and pathogenic bacteria in secondary effluents and lake water by solar disinfection (SODIS). J Water Reuse Desalination 3(1):39-46

Al-Gheethi AAS, Norli I, Lalung J, Azieda T, Kadir MO (2013b) Reduction of faecal indicators and elimination of pathogens from treated sewage by heat treatment. Caspian J Appl Sci Res 2(2):29-45

Al-Gheethi AAS, Norli I, Lalung J, Azieda T, Efaq AN, Kadir MO (2013c) Susceptibility for antibiotics among faecal indicators and pathogenic bacteria in sewage treated effluents. Water Pract Technol 8(1):1-6

Al-Gheethi AAS, Abdul-Monem MO, AL-Zubeiry AHS, Efaq AN, Shamar AM, Al-Amery RMA (2014) Effectiveness of selected wastewater treatment plants in Yemen for reduction of faecal indicators and pathogenic bacteria in secondary effluents and sludge. Water Pract Technol 3(3):293-306

Al-Gheethi AA, Norli I, Efaq AN, Bala JD, Al-Amery R (2015) Solar Disinfection and lime treatment processes for reduction of pathogenic bacteria in sewage treated effluents and biosolids before reuse for agriculture in Yemen. Water Reuse Desalination 5(3):419-429

Al-Gheethi AA, Mohamed RMS, Efaq AN, Norli I, Amir Hashim MO, Kadir Ab (2016a) Bioaugmentation Process of Sewage Effluents for the Reduction of Pathogens, heavy metals and antibiotics. J Water Health 14(5):780-795

Al-Gheethi AA, Mohamed RM, Efaq AN, Amir HK (2016b) Reduction of microbial risk associated with greywater utilized for irrigation. Water Health J 14(3):379-398

Al-Gheethi AA, Mohamed RM, Efaq AN, Adib MR, Ismail N (2017) Reduction of bacteria in storage system of sewage effluents. J Sustain Water Resour Manag 3:193-203

Al-Jaboobi M, Bouksaim M, Tijane M, EL-Ariqi S (2013) Agricultural quality evaluation of wastewater, used in Yemen vegetables production. Mid East J Sci Res 16(5):667-677

Al-Jasser AO (2011) Saudi wastewater reuse standards for agricultural irrigation: riyadh treatment plants effluent compliance. J King Saud Univ Eng Sci 23(1):1-8

Alonso E, Santos A, Riesco P (2004) Microorganism regrowth wastewater disinfected by UV radiation and ozone: a microbiological study. Environ Technol 25(4):433-441

Al-Rekabi WS, Qiang H, Qiang WW (2007) Improvements in wastewater treatment technology. Pak J Nutr 6(2):104-110

Al-Sabahi E, Abdul-Rahim S, Wan-Zuhairi WY, Alshaebi F, Al Nozaily F (2009) Assessment of groundwater and surface water pollution at Mitm Area, Ibb City, Yemen. Am J Appl Sci 6(4):772-783

Al-Saed R (2007) Pathogens assessment in reclaimed effluent used for industrial crops irrigation. Int J Environ Res Public Health $4(1): 68-75$

Al-Sharabee R (2009) The effect of using wastewater on microbiological pollution for vegetable crops, MSc Thesis, Faculty of Agriculture, Sana'a University, Yemen

Alvarez-Ordonez A, Begley M, Prieto M, Messens M, Lopez M, Bernardo A, Hill C (2011) Salmonella spp. survival strategies within the host gastrointestinal tract. J Microbiol 157(12):3268-3281

Al-Zubeiry AHS (2005) Microflora inhabiting raw sewage, secondary effluent and dewatered sludge in Ibb, Yemen Republic. Ass Univ Bull Environ Res 8(1):1-16

Amer AA (1997) Destruction of sludge pathogenic bacteria using quick lime and cement dust. J Soil Sci 37:343-354

APHA (1989) Standard methods for the examination of water and wastewater, 17th edn. American Public Health Association, Washington
APHA (1998) Standard methods for the examination of water and wastewater, 20th edn. American Public Health Association, Washington

Ashbolt NJ, Grabow WOK, Snozzi M (2001) Indicators of microbial water Association, Washington

Astals S, Venegas C, Peces M, Jofre J, Lucena F, Mata-Alvarez J (2012) Balancing hygienization and anaerobic digestion of raw sewage sludge. Water Res 46(19):6218-6227

Avery LM, Killham K, Jones DL (2005) Survival of E. coli O157: H7 in organic wastes destined for land application. J Appl Microbiol 98:814-822

Bala JD, Yusuf IZ, Tahir F (2012) Bacteriological assessment of pharmaceutical wastewater and its public health implications in Nigeria. IUP J Biotechnol 6(1):34-50

Baloda SB, Krovacek K (1994) Use of polymerase chain reaction (PCR) technology in the detection of foodborne pathogens: an overview. In: Proceedings of International Congress on "Quality of Veterinary Services for the 21st Century"; Kuala Lumpur, 1994; pp 123-126

Barbagallo S, Brissaud F, Cirelli GL, Consoli S, Xu P (2003) Modeling of bacterial removal in wastewater storage reservoir for irrigation purposes: a case study in Sicily, Italy. Water Sci Technol 3(4):169-175

Bataller M, Veliz E, Fernandez LA, Hernandez C, Fernandez I, Alvarez C, Sanchez E (2005) Secondary effluent treatment with ozone. In: IOA 17th World Ozone Congress Straboung 2005. p 1-9

Baudišová D (2009) Microbial pollution of water from agriculture. Pant Soil Environ 55(10):429-435

Berney M, Weilenmann HU, Simonetti A, Egli T (2006) Efficacy of solar disinfection of E. coli, S. flexneri, S. typhimurium and $V$. cholera. J Appl Microbiol 101(4):828-836

Bina B, Movahedian H, Kord I (2004) The effect of lime stabilization on the microbiological quality of sewage sludge. Iranian J Environ Health Sci Eng 1(1):34-38

Bitton G (2005a) Wastewater microbiology, 3rd edn. Wiley, Hoboken, $\mathrm{p} 746$

Bitton G (2005b) Microbial indicator of faecal contamination: Application to microbial source tracking. Report submitted to the Florida Storm water Association. Association 719 East Park Avenue, Tallahassee, 32301. University of Florida

Block SS (2001) Disinfection, sterilization, and preservation, 5th edn. Lippincott Williams and Wilkins, Lippincott Williams and Wilkins

Bohm R (2004) Hygienic safety in organic waste management. In: Lens P, Hamerels B, Hoitink H, Bidlingmaier W (eds) Resource, recovery and reuse in organic solid waste management. IWA Publishing, London

Brenner DJ, Krieg NR, Staley JT (2005) Bergey's manual of systematic bacteriology, vol 2, proteobacteria, Parts A, B and C. Williams and Wilkins Awaverly Co, Philadelphia

Burtscher C, Wuertz S (2003) Evaluation of the use of PCR and reverse transcriptase PCR for detection of pathogenic bacteria in biosolids from anaerobic digestors and aerobic composters. Appl Environ Microbiol 69(8):4618-4627

Byappanahalli MN, Fujioka RS (1998) Evidence that tropical soil environment can support the growth of E. coli. Water Sci Technol 38(12):171-174

Carlander A (2006) Assessment of microbial health hazards associated with wastewater application to willow coppice, coniferous forest and wetland systems. Ph. D. Thesis. University of Agricultural Sciences, Swedish

Carrington EG, Davis RD, Hall JE, Pike EB, Smith SR, Unwin RJ (1998) Review of the scientific evidence relating to the controls on the agricultural use of sewage sludge. Report DETR 4415/3 [part1] and Report DETR 4454/4 [part 2] WRc plc, Medmenham

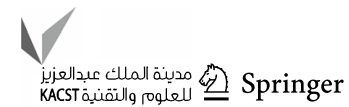


Carvalho FG, Teixeira L (2002) History, taxonomy, biochemical characteristics, and antibiotic susceptibility testing of enterococci. The enterococci: pathogenesis, molecular biology, and antibiotic resistance. ASM Press, Washington

Casey TJ (1997) Unit treatment processes in water and wastewater engineering. Wiley, Chichester

CDPH (2009) Treatment technology report for recycled water. California Department of Public Health, State of California Division of Drinking Water and Environmental Management, Sacramento

Celico F, Varcamonti M, Guida M, Naclerio G (2004) Influence of precipitation and soil on transport of faecal enterococci in fractured limestone aquifers. Appl Environ Microbiol 70(5):2843-2847

Ceustermans A, De Clercq D, Aertsen A, Michiels C, Geeraerd A, Van Impe J, Coosemans J, Ryckeboer J (2007) Inactivation of Salmonella Senftenberg strain W 775 during composting of biowastes and garden wastes. J Appl Microbiol 103(1):53-64

CFR (1995) Standards for the use or disposal of sewage sludge. Title 40, Part 503

Chen YC, Higgins MJ, Beightol SM, Murthy SN, Toffey WE (2011) Anaerobically digested biosolids odor generation and pathogen indicator regrowth after dewatering. Water Res 45(8):2616-2626

Chen Y, Fu B, Wang Y, Jiang Q, Liu H (2012) Reactor performance and bacterial pathogen removal in response to sludge retention time in a mesophilic anaerobic digester treating sewage sludge. Biores Technol 106:20-26

Choi JW, Sherr EB, Sherr BF (1996) Relation between presenceabsence of a visible nucleoid and metabolic activity in bacterioplankton cells. Limnol Oceanogr 41:1161-1168

Choi JW, Sherr BF, Sherr EB (1999) Dead or alive? A large fraction of ETS-inactive marine bacterioplankton cells, as assessed by reduction of CTC, can become ETS-active with incubation and substrate addition. Aquat Microb Ecol 18(9):105-115

Cooper RC, Olivieri AW (1998) Infectious disease concerns in wastewater reuse. In: Asano T (ed) Wastewater reclamation and reuse. Technomic Publishing Company, Lancaster, pp 489-520

Coronel-Olivares C, Reyes-Gomez LM, Hernandez-Munoz A, Martinez-Falcon AP, Vazquez-Rodríguez GA, Iturbe U (2011) Chlorine disinfection of $P$. aeruginosa, total coliforms, E. coli and E. faecalis: revisiting reclaimed water regulations. Water Sci Technol 64(11):2151-2157

Cotruvo JA, Rees ADG, Bartram J, Carr R, Cliver DO, Craun GF, Fayer R, Gannon VPJ (2004) Waterborne zoonoses: identification, causes and control. World Health Organization, London

County K (2005) Biosolids quality summary. Department of Natural Resources and Parks Wastewater Treatment. Division Technology Assessment and Resource Recovery, 201. S. Jackson Street, KSC-NR-0512 Seattle, Washington 98104-3855

Crook J (1998) Water reclamation and reuse criteria. Water Sci Technol 33(10-11):451-462

Cunault C, Pourcher AM, Burton CH (2011) Using temperature and time criteria to control the effectiveness of continuous thermal sanitation of piggery effluent in terms of set microbial indicators. J Appl Microbiol 111(6):1492-1504

Dalkmann P, Broszat M, Siebe C, Willaschek E, Sakinc T, Huebner H, Amelung W, Grohmann E, Siemens J (2012) Accumulation of pharmaceuticals, Enterococcus, and resistance genes in soils irrigated with wastewater for zero to 100 years in Central Mexico. PLoS One 7(9):e45397. https://doi.org/10.1371/journ al.pone. 0045397

Dancer SJ (2004) How do we assess hospital cleaning? A proposal for microbiological standards for surface hygiene in hospitals. J Hospital Infect 56:10-15

Dumontet S, Dinel H, Baloda SB (1999) Pathogen reduction in sewage sludge by composting and other biological treatments: a review. Biol Agric Hortic 16(4):409-430
Dumontet S, Scopa A, Kerje S, Krovacek K (2001) The importance of pathogenic organisms in sewage and sewage sludge. J Air and Waste Manag Assoc 51:848-860

Dungeni M, Merwe RR, Momba MNB (2010) Abundance of pathogenic bacteria and viral indicators in chlorinated effluents produced by four wastewater treatment plants in the Gauteng Province, South Africa. Water SA 36(5):607-614

Dutta M, Dutta NN, Bhattacharya KG (1999) Aqueous phase adsorption of certain beta-lactam antibiotics onto polymeric resins and activated carbon. Separ Purif Technol 16(3):213-224

Edberg SC, Allen MG, Smith DB, Kriz NJ (1990) Enumeration of total coliforms and $E$. coli from source water by the defined substrate technology. Appl Environ Microbiol 56(2):366-369

Efaq AN, Rahman Nik Norulaini Nik Ab, Nagao H, Al-Gheethi AA, Shahadat Md, Kadir MO (2015) Supercritical carbon dioxide as non-thermal alternative technology for safe handling of clinical wastes. J Environ Process 2(4):797-822

Efaq AN, Ab Nik Norulaini Nik, Rahman Nagao H, Al-Gheethi AA, Kadir MO (2017) Inactivation of aspergillus spores in clinical wastes by supercritical carbon dioxide. AJSE 42(1):39-51

Ellafi A, Abdallah F, Bakhrouf A (2010) Effect of starvation on survival and adhesion ability of Shigella spp. in domestic treatment plant effluent microcosms. J Ann Microbiol 60(3):383-389

El-Lathy MA, El-Taweel GE, El-Sonosy WM, Samhan FA, Moussa TAA (2009) Determination of pathogenic bacteria in wastewater using conventional and PCR techniques. Environ Biotechnol $5(2): 73-80$

Enerhall C, Stenmark E (2012) Disc Filters to Reduce Wastewater Pathogen Levels in Raw Water Sources. Master of Science Thesis in the Master's Programme Geo and Water Engineering. Department of Civil and Environmental Engineering Division of Water Environment Technology, Chalmers University of Technology. Göteborg, Sweden 2012

Espigares E, Bueno A, Espigares M, Galvez R (2006) Isolation of Salmonella serotypes in wastewater and effluent: effect of treatment and potential risk. Int J Hyg Environ Health 209:103-107

Facile N, Barbeau B, Prevost M, Koudjonou B (2000) Evaluating bacterial aerobic spores as a surrogate for Giardia and Cryptosporidium inactivation by ozone. Water Res 34(12):3238-3246

FAO (2008) Irrigation in the Middle East region in figures. Aquastat survey 2008. In: Frenken K (Ed.) Land and Water Division. Food and Agriculture Organization. FAO Water Reports 34

Farzadkia M, Bazrafshan E (2014) Lime stabilization of waste activated sludge. Health Scope J 3(1):1-5

Fijalkowski KL, Kacprzak MJ, Rorat A (2014) Occurrence changes of Escherichia coli (including O157:H7 serotype) in wastewater and sewage sludge by quantitation method of (EMA) real time-PCR. Desalination Water Treat 52:19-21

Fine P, Atzmon N, Adani F, Hass A (2006) Disposal of sewage effluent and biosolids in eucalyptus plantations: a lysimeter simulation study. Soil Water Pollut Monit Prot Rem 3(23):433-453

Fittipaldi M, Nocker A, Codony F (2012) Progress in understanding preferential detection of live cells using viability dyes in combination with DNA amplification. J Microbiol Methods 91(2):276-289

Fratamico PM, Bhunia AK, Smith JL (2005) Foodborne pathogens microbiology and molecular biology. Horizon Scientific Press, Poole

Fujioka RS (1997) Indicators of marine recreational water quality. In: Hurst CJ, Knudsen GR, McInerney MJ, Stezenbach LD, Walter MV (eds) Manual of environmental microbiology. ASM Press, Washington, pp 176-183

Garcia-Armisen T, Vercammen K, Passerat J, Triest D, Servais P, Cornelis P (2011) Antimicrobial resistance of heterotrophic bacteria in sewage-contaminated rivers. Water Res 45(2):788-796 
Gasoll GM, Giorgio A, Massana R, Duarte CM (1995) Active versus inactive bacteria: size-dependence in a coastal marine plankton community. Mar Ecol Prog Ser 128:91-97

Gebra CP (1996) Microbial pathogens in municipal solid waste. In: Palmisano AC, Barlaz MA (eds) Microbiology of solid waste. CRC Press, Boca Raton, pp 71-104

Geldreich EE (1978) Bacterial populations and indicator concepts in feces, sewage, storm water and solid wastes. In: Berg G (ed) Indicators of viruses in food and water. Ann Arbor Science Publishers, Ann Arbor, pp 51-97

Geldreich E (1996) Microbial quality of water supply in distribution systems. CRC, Boca Raton, pp 76-78

Ghazala S, Ramaswamy S, Smith JP, Simpson BK, Simpson MV (1991) Establishing sous-vide processing schedules for spaghetti/meat sauce and rice/salmon based on thermal destruction of Streptococcus faecium. In: Proceedings of 18th International Congress of Refrigeration. Quebec, Montreal

Gomez M, Rua A, Garralon G, Plaza F, Hontoria E, Gomez MA (2006) Urban wastewater disinfection by filtration technologies. Desalination 190(1-3):16-28

Gomez-Couso H, Fontan-Sainz M, Sichel C, Fernandez-Ibanez P, Ares-Mazas E (2009) Efficacy of the solar water disinfection method in turbid waters experimentally contaminated with Cryptosporidium parvum oocysts under real field conditions. Trop Med Int Health 14(6):620-627

Gopakumar K, Ayyappan S, Jena JK (2000) Present status of integrated fish farming in India and wastewater treatment through aquaculture proceedings of the national workshop on wastewater treatment and integrated aquaculture, Edited, Kumar M.S. SARDI Aquatic Sciences 17-19th pp. 22-37

Gordon DM, Bauer S, Johnson JR (2002) The genetic structure of $E$. coli populations in primary and secondary habitats. J Microbiol 148(5):1513-1522

Gupta RA, Khan P, Saxena S, Mohapatra H (2000) Microbial biosorbents: meeting challenges of heavy metal pollution in aqueous solutions. Review article. J Curr Sci 78(8):967-973

Haidar A (2005) Environmental impact to use wastewater in agricultural irrigation (Ibb, Sana'a, Thammar), dar Al-Kutub Ministry of Culture- Sana'a, 397: 1110

Han II, Congeevaram S, Ki D, Oh B, Park J (2011) Bacterial community analysis of swine manure treated with autothermal thermophilic aerobic digestion. Appl Microbiol Biotechnol 89(3):835-842

Hansen JJ, Warden PS, Margolin AB (2007) Inactivation of Adenovirus type 5, Rotavirus WA and male specific coliphage $\left(\mathrm{MS}_{2}\right)$ in biosolids by lime stabilization. Int J Environ Res 4(1):61-67

Harrison EZ, McBride MB, Bouldin DR (1999) Land application of sewage sludges: an appraisal of the US regulations. Int J Environ Pollut 11(1):1-36

Heng LY, Abdullah P, Yi CS, Mokhtar M, Ahmad R (2006) Development of possible indicators for sewage pollution for the assessment of Langat river ecosystem health. Malaysia J Anal Sci 10(1):15-26

Heritage J, Evans EG, Killington RA (2003) Microbiology in action. Cambridge University Press, New York, pp 10011-14211

Heyman D (2004) Control of communicable diseases manual, 18th edn. American Public Health Association, Washington

Himathongkham S, Riemann H (1999) Destruction of S. typhimurium, E. coli $\mathrm{O} 157: \mathrm{H} 7$ and L. monocytogenes in chicken manure by drying and/or gassing with ammonia. FEMS Microbiol Lett 171(2):179-182

Horman A, Rimhanen-Finne R, Maunula L, von Bonsdorff C, Torvela N, Heikinheimo A, Hanninen M (2004) Campylobacter spp., Giardia spp., Cryptosporidium spp., Noroviruses, and indicator organisms in surface water in Southwestern Finland, 2000-2001. Appl Environ Microbiol 70(1):87-95

Ibenyassine K, Mhand RA, Karamoko Y, Anajjar B, Chouibani M, Ennaj MM (2007) Bacterial pathogens recovered from vegetables irrigated by wastewater in Morocco. J Environ Health 69(10):47-51

Jagger J (1985) Solar-UV actions on living cells, 1st edn. Praeger Publishers, New York

Janex ML, Savoye P, Xu P, Rodriguez J, Lazarova V (2000) Ozone for Urban Wastewater Disinfection: A New Efficient Alternative Solution. In: Proceedings of the Specialized Conference on Fundamental and Engineering Concepts for Ozone Reactor Design, Toulouse, France; International Ozone Association: Stamford, Connecticut; pp 95-98

Jiang Q, Fu B, Chen Y, Wang Y, Liu H (2013) Quantification of viable but nonculturable bacterial pathogens in anaerobic digested sludge. Appl Microbiol Biotechnol 97(13):6043-6050

Jin P, Jin X, Wang XC, Shi X (2013) An analysis of the chemical safety of secondary effluent for reuse purposes and the requirement for advanced treatment. Chemosphere 91(4):558-562

John MP (2005) The use of biosolids in Maine: A review. Biosolids White Paper. Senator George J. Mitchell. Center for Environmental and Watershed Research. University of Maine, Orono, Maine

Jokinen CC, Schreier H, Mauro W, Taboada E, Isaac-Renton JL, Topp E, Edge T, Thomas JE, Gannon VPJ (2010) The occurrence and sources of Campylobacter spp., Salmonella enterica and Escherichia coli O157:H7 in the Salmon River, British Columbia, Canada. J Water Health 8(2):374-386

Joux F, LeBaron P (1997) Ecological implications of an improved direct viable count method for aquatic bacteria. Appl Environ Microbiol 63:3643-3647

Jury KL, Vancov T, Stuetz RM, Khan SJ (2010) Antibiotic resistance dissemination and sewage treatment plants. In: Current Research Technology and Education Topics in Applied Microbiology and Microbial Biotechnology. A Mendez-Vilas (Ed). pp 509-519

Kabrick RM, Jewell WJ (1982) Fate of pathogens in thermophilic aerobic digestion. Water Res 16:1051-1060

Kaper JB, Nataro JP, Mobley HL (2004) Pathogenic E. coli. Nat Rev Microbiol 2:123-140

Katterman FRH, Day AD (1989) Plant growth factors in sewage sludge. J BioCycle 30(3):64-65

Keller R, Passamani F, Vaz L, Cassini ST, Goncalves RF (2003) Inactivation of Salmonella spp. from secondary and tertiary effluents by UV irradiation. Water Sci Technol 47(3):147-150

Kim J, Hahn J, Franklin MJ, Stewart PS, Yoon J (2009) Tolerance of dormant and active cells in Pseudomonas aeruginosa PA01 biofilm to antimicrobial agents. J Antimicrob Chem 63:129-135

Kimberly LA, John EW, Valerie JH (2005) Persistence and differential survival of faecal indicator bacteria in subtropical waters and sediments. Appl Environ Microbiol 71(6):3041-3048

Klavarioti M, Mantzavinos D, Kassinos D (2009) Removal of residual pharmaceuticals from aqueous systems by advanced oxidation processes. J Environ Int 35(2):402-417

Koivunen J, Siitonen A, Heinonen-Tanski H (2003) Elimination of enteric bacteria in biological-chemical wastewater treatment and tertiary filtration units. Water Res 37(3):690-698

Kollu K, Ormeci B (2012) Effect of particles and bio-flocculation on ultraviolet disinfection of $E$. coli. Water Res 46(3):750-760

Kowal NE (1983) An overview of public health effects. In: Page AL, Gleason TL, Smith JE, Iskander IK, Sommers LE (eds) Utilization of municipal wastewater and sludge on land. University of California, Riverside, pp 329-394

Laroche E, Pawlak B, Berthe T, Skurnik D, Petit F (2009) Occurrence of antibiotic resistance and class 1,2 and 3 integrons in E. coli 
isolated from a densely populated estuary (Seine, France). FEMS Microbiol Ecol 68(1):118-130

Leduc R, Gehr R (1990) Removal of coliform bacteria from aerated stabilisation lagoons 1 Kinetics, modelling and biotic variable. Water pollut Res J Can 25:231-263

Leeming R, Nichols PD, Ashbolt N (1998) Distinguishing sources of faecal pollution in Australia inland and coastal waters using sterol biomarkers and microbial faecal indicators. UWRAA Research Report 204, Water Services Association of Australia, Melbourne, Australia

Lepeuple AS, Gaval G, Jovic M, Recherche MR (2004) Literature review on levels of pathogens and their abatement in sludges, soil and treated biowaste. Horizontal WP3: Hygienic parameters

Lisle JT, Smith JJ, Edwards DD, Mcfeters GA (2004) Occurrence of microbial indicators and Clostridium perfringens in wastewater, water column samples, sediments, drinking water and weddell seal feces collected at Memurdo station, Antarctica. Appl Environ Microbiol 70:7269-7276

Liu C (2000) Pathogen inactivation in biosolids with lime and fly ash addition. M. Sc. Thesis, Environmental Engineering University, Manitoba

Lucero-Ramirez B (2000) The effects of time and temperature on the fate of pathogens and indicator bacteria during municipal wastewater sludge-mesophilic anaerobic digestion, air-drying and composting, Ph.D. Thesis, University of Texas, Austin, USA

Luczkiewicz A, Jankowska K, Fudala-Ksiazek S, Olanczuk-Neyman K (2010) Antimicrobial resistance of faecal indicators in municipal wastewater treatment plant. Water Res 44(17):5089-5097

Luna GM, Manini E, Danovaro R (2002) Large fraction of dead and inactive bacteria in coastal marine sediments: comparison of protocols for determination and ecological significance. Appl Environ Microbiol 68(7):3509-3513

Markosyan LS, Vardanyan N, Paronyan AKH, Nikoghosyan VG, Delalio A (2002) Microflora and chemical characteristics of wastewater sludge. Biol J Armenia 54:31-41

Maynard HE, Ouki M, Williams SC (1999) Tertiary Lagoons: a review of removal mechanisms and performance. Water Res 33(1):1-13

Meierhofer R, Wegelin M (2002) Solar water disinfection -a guide for the application of SODIS. Swiss Federal Institute of Environmental Science and Technology (EAWAG/SANDEC), Switzerland

Ministry of Agriculture and Irrigation (2012) A Promising sector for Diversified Economy in Yemen: National Agriculture Sector Strategy 2012-2016, March 2012

Moce-Llivina L, Muniesa M, Pimenta-Vale H, Lucena F, Jofre J (2003) Survival of bacterial indicator species and bacteriophages after thermal treatment of sludge and sewage. Appl Environ Microbiol 69:1452-1456

Mohamed RM, Al-Gheethi AA, Jackson AM, Amir HK (2016) Multi component filters for domestic greywater treatment in village houses. J Am Water Works Assoc (AWWA) 108(7):405-414

Mote BL, Turner JW, Lippa EK (2012) Persistence and growth of the faecal indicator bacteria enterococci in detritus and natural estuarine plankton communities. Appl Environ Microbiol 78(8):2569-2577

Munir M, Wong K, Xagoraraki I (2010) Release of antibiotic resistant bacteria and genes in the effluent and biosolids of five wastewater utilities in Michigan. Water Res 45(2):681-693

Munir M, Wong K, Xagoraraki I (2011) Release of antibiotic resistant bacteria and genes in the effluent and biosolids of five wastewater utilities in Michigan. Water Res 45(2):681-693

Myers DN, Stoeckel DM, Bushon RN, Francy DS, Brady AMG (2007) Faecal indicator bacteria. US Geological Survey Techniques of Water Resources Investigations. Book 9, chapter A7, section 7.1 (version 2.0)
N'Dayegamiye A, Huard S, Thibault Y (2002) Paper mill sludge (biosolids) applications in agriculture: agronomic and environmental impacts. In: International Environmental Conference and Exhibit, TAPPI, Montreal, April 6-10, 2002, p 6

Nasser AM, Paulman H, Sela O, Ktaitzer T, Cikurel H, Zuckerman I, Meir A, Aharoni A, Adin A (2006) UV disinfection of wastewater effluents for unrestricted irrigation. Water Sci Technol 54(3):83-88

Neis U, Blume (2002) Ultrasonic disinfection of wastewater effluents for high-quality reuse. IWA Regional Symposium on Water Recycling in Mediterranean Region, Iraklio, Greece, 26.-29.09

Nicholson FA, Hutchinson ML, Smith KA, Keevil CW, Chambers BJ, Moore A (2000) A study on farms manure applications to agricultural land and an assessment of the risks of pathogens transfer into the food chain. Report to MAFF, Project No. FS2526

Niyogi SK (2005) Shigellosis. J Microbiol 43(2):133-143

Nowak O (2007) Optimizing the use of sludge treatment facilities at municipal WWTPs. J Environ Sci Health 41(9):1807-1817

Oliver JD (2005) The viable but non-culturable state in bacteria. J Microbiol 43:93-100

Onnis-Hayden A, Hsu BB, Klibanov AM, Gu AZ (2011) An antimicrobial polycationic sand filter for water disinfection. Water Sci Technol 63(9):1997-2003

Palmgren H (2002) Importance of wild birds in the spread of Salmonella. $\mathrm{Ph}$. D. Thesis. Umea University

Paraskeva P, Graham NJD (2002) Ozonation of municipal WASTEWATER EFflUENTS. Water Environ Res 74(6):569-580

Pauwels B, Verstraete W (2006) The treatment of hospital wastewater: an appraisal. J Water Health 4(4):405-416

Payment P, Franco E (1993) Clostridium perfringens and somatic coliphages as indicators of the efficacy of drinking water treatment for viruses and protozoan cysts. Appl Environ Microbiol 59:2418-2424

Payment P, Godfree A, Sartory D (2002) Clostridium. In: Bitton G (ed) Encyclopedia of environmental microbiology. Wiley, Hoboken, pp 861-871

Pehlivanoglu-Mantas E, Elisabeth L, Hawley R, Deeb A, Sedlak DL (2006) Formation of nitrosodimethylamine (NDMA) during chlorine disinfection of wastewater effluents prior to use in irrigation systems. Water Res 40(2):341-347

Peng X, Luo W, Zhang J, Wang S, Lin S (2002) Rapid Detection of Shigella Species in Environmental Sewage by an Immunocapture PCR with Universal Primers. Appl Environ Microbiol 68(5):2580-2583

Placha I, Venglovsky J, Sasakova N, Svoboda IF (2001) The effect of summer and winter season on the survival of S. typhimurium and indicator microorganisms during the storage of solid fraction of pig slurry. J Appl Microbiol 91:1-8

Plachy P, Placha I, Juris P (1996) Use of hydrated lime for disinfection of model pathogens $S$. typhimurium and Ascaris suum in sewage sludge. In: Hygienic and ecological problems in relation to veterinary medicine. Proceedings of International Conference and Veterinary Medicine III. Kosice- Slovak Republic

Polo FMJ, Figueras I, Inza J, Sala JM, Fleisher JG (1998) Relationship between presence of Salmonella and indicators of faecal pollution in aquatic habitats. FEMS Microbiol Lett 160:253-256

Qing W, Yan L, Ming W, Xiao PP, Yong FT (2010) Fluorescence in situ hybridization rapidly detects three different pathogenic bacteria in urinary tract infection samples. J Microbiol Methods $83: 175-178$

Rao DG, Senthilkumar R, Byrne A, Feroz S (2012) Wastewater treatment: Advanced processes and technologies. In: Thanikal V (ed) Anaerobic fixed bed reactor for treatment of industrial wastewater Joseph. CRC Press, Boca Raton, pp 335-354 
Reimers RS (1997) Disinfection of pathogens by biosolids processing, US EPA Region VI. Biosolids stabilization and disinfection-what are our concerns. Water Environment Federation. Alexandria. VA (Dallas, TX). pp 1-4

Reinosoa R, Alexandra L, Bécaresb TE (2008) Efficiency of natural systems for removal of bacteria and pathogenic parasites from wastewater. J Sci Total Environ 395(2-3):80-86

Riley LW, Remis RS, Helgerson D, McGee HB, Wells JG, Davis BR, Hebert RJ, Olcott ES, Johnson LM, Hargrett NT, Blake PA, Cohen ML (1983) Hemorrhagic colitis associated with a rare Escherichia coli serotype. New Engl J Med 308(12):681-685

Rizzo L, Fiorentino A, Anselmo A (2013) Advanced treatment of urban wastewater by UV radiation: effect on antibiotics and antibioticresistant E. coli strains. Chemosphere 92(2):171-176

Ronner AB, Wong CL (1993) Biofilm development and sanitizer inactivation of Listeria monocytogenes and Salmonella typhimurium on stainless steel and Bunan rubber. J Food Protect 56:750-758

Rose JB, Farrah SR, Harwood VJ, Levine AD, Lukasik J, Menendez P, Scott TM (2004) Reduction of pathogens, indicators bacteria and alternative indicators by wastewater treatment and reclamation processes. Water Environ Res Found, USA

Rouch DA, Mondal T, Pai S, Glauche G, Fleming VA, Thurbon N, Blackbeard J, Smith SR, Deighton M (2011) Microbial safety of air-dried and rewetted biosolids. J Water Health 9(2):403-414

Sahlstrom L, Aspan A, Bagge E, Danielsson-Tham ML, Albihn A (2004) Bacterial pathogen incidences in sludge from Swedish sewage treatment plants. Water Res 38:1989-1994

Sahlstrom L, De Jong B, Aspan A (2006) Salmonella isolated in sewage sludge traced back to human cases of salmonellosis. Lett Appl Microbiol 43:46-52

Saleem A, Al-Malack MH, Bukhari AA (2001) Seasonal variation in the microbial population density present in biological sludge. Environ Technol 22:55-259

Samhan AS, Al-Saed RM, Mahmoud NJ (2007) Removal of pathogenic microorganisms in pilot-scale uasb-septic tanks and Albireh urban wastewater treatment plant in Palestine. Water Int J 32(5):787-798

Santhiya G, Lakshumanan C, Selvin J, Asha D (2011) Microbiological analysis of seawater and sediments in urban shorelines: occurrence of heavy metals resistance bacteria on Chennai beaches. Bay Bengal Microchem J 99(2):197-202

Sasdkovd N, Vargov M, Ondraovidovd O, Ondraovic M, Kottferovd J, Venglovskf J, Culenova K, Hromada R, Papajovd I (2005) The influence of the amendment of sewage sludge with zeolite and lime from the microbiological point of view. Folia Vet 49(3):26-27

Schwartzbrod J, Gaspard P, Ambolet Y (1997) Urban sludge reused for agricultural purposes: soils contamination and model development for the parasitological risk assessment. Bull Acad Med 181:43-57

Scott TM, McLaughlin MR, Harwood VJ, Chivukula V, Levine A, Gennaccaro A, Lukasik J, Farrah SR, Rosem JB (2003) Reduction of pathogens, indicator bacteria, and alternative indicators by wastewater treatment and reclamation processes. Water Sci Technol, Water Supply 3(4):247-252

Servais P, Passerat J (2009) Antimicrobial resistance of faecal bacteria in waters of the Seine river watershed (France). J Sci Environ 408(2):365-372

Sidhu JPS, Toze SG (2009) Human pathogens and their indicators in biosolids: a literature review. Environ Int 35(1):187-201

Siti Khadijah E, Haque AM, Murshed MF (2013) Performance of sewage oxidation pond in USM engineering campus. Caspian J Appl Sci Res 2(12):219-225

Smith JP, Toupin C, Gagnon B, Voyer R, Fiset PP, Simpson MVA (1990) Hazard analysis critical control point approach
(HACCP) to ensure the microbiological safety of sous vide processed meat/pasta product. Food Microbiol 7(3):177-198

Smith SR, Lang NL, Cheung KH, Spanoudaki K (2005) Factors controlling pathogen destruction during anaerobic digestion of biowastes. Waste Manag 25(4):417-425

Spongberg AL, Witter JD (2008) Pharmaceutical compounds in the wastewater process stream in Northwest Ohio. J Sci Environ 397(1-3): 148-157

Springthorpe S, Sattar SA (2004) The Biological issues related to use of a pelletizer for the decontamination of biosolids in Toronto. A report prepared for Jacques Whitford Environment Limited July 2004

Straub TM, Pepper IL, Gerba CP (1993) Hazards from pathogenic microorganisms in land-disposed sewage sludge. Rev Environ Contam Toxicol 132:55-91

Suresh DP, Kenneth WW, Scot ED, Steven CR (1996) Occurrence of airborne bacteria and pathogen indicators during land application of sewage sludge. Appl Environ Microbiol 1(62):296-299

Svoboda IS, Carcluie C (2003) Anaerobic digestion, storage, oligolysis, lime, heat and aerobic treatment of livestock manures. Provision of research and design of pilot schemes to minimize livestock pollution to the water environment in Scotland. QLC 9/2. FEC Services Ltd, Kenilworth, Warwickshire, pp 1-110

Synnott AJ, Kuang Y, Kurimoto M, Yamamichi K, Iwano H, Tanji Y (2009) Isolation from sewage influent and characterization of novel $S$. aureus bacteriophages with wide host ranges and potent lytic capabilities. Appl Environ Microbiol 75(13):4483-4490

Telles CB, Tavares CRG, Filho BPD, Moitinho MLR (2002) Operation of a slow rate anaerobic digester treating municipal secondary sludge. Electron J Biotechnol 5(3):216-227

Ting GM, Huang J, Hu H, Liu W (2011) Growth and repair potential of three species of bacteria in reclaimed wastewater after UV disinfection. Biomed Environ Sci 24(4):400-407

Toth JD, Aceto HW, Rankin SC, DebRoy C, Dou Z (2012) Accelerating the deactivation of Salmonella enterica serovar newport and Escherichia coli $\mathrm{O} 157: \mathrm{H} 7$ in dairy manure by modifying $\mathrm{pH}$ or temperature. Open Waste Manag J 5:11-18

Toze S (1997) Microbial pathogens in wastewater. Literature review for urban water systems multi-divisional research program. Technical report no 1/97 CSIRO, Australia

Tree JA, Adams MR, Lees DL (2003) Chlorination of Indicator bacteria and viruses in primary sewage effluent. Appl Environ Microbiol 69(4):2038-2043

Tripathi S, Pathak V, Tripathi DM, Tripathi BD (2011) Application of ozone based treatments of secondary effluents. J Biores Technol 102(3):2481-2486

Tyagi VK, Chopra AK, Kazmi AA, Kumar A (2006) Alternative microbial indicators of faecal pollution: current perspective. Iran J Environ Health Sci Eng 3(3):205-216

UN (2003) Economic and social commission for Western Asia wastewater treatment technologies: a general review. United Nations, Distr. General E/ESCWA/SDPD

UN (2012) Status and new developments on the use of brackish water for agricultural production in the Near East. Yemen Country Report. Prepared by: Eng. Abdulkarim Al-Sabri Edited by: Dr. Mary K. Halim. United Nations, Cairo, Egypt, November 2012

UNICEF (2013) Children dying daily because of unsafe water supplies and poor sanitation and hygiene. United Nations Children's Fund, USA

US EPA (1986a) Bacteriological ambient water quality criteria for marine and fresh recreational waters. EPA 440/5-84-002. US Environmental Protection Agency, Office of Research and Development, Cincinnati, $\mathrm{OH}$

US EPA (1986b) Design manual municipal wastewater disinfection. Environmental Protection Agency, EPA/625/1-86/021

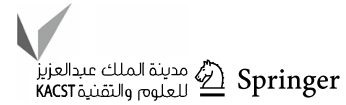


US EPA (1988) Occurrence of pathogens in distributed and marketing municipal sludge project summary by Yanko, M. US Environmental Protection Agency. EPA/600/SI-87/014

US EPA (1992) Environmental regulations technology control of pathogens and vector attraction in sewage sludge. EPA/625/R-92/01

US EPA (1993) The standards for the use of disposal of sewage sludge. Final CFR Part 503 Rules. EPA 822/Z-93/001. USEPA, Office of Water, Washington, DC

US EPA (1995) Pathogen risk assessment methodology for municipal sewage sludge land filling and surface disposal. US EPA/00/R-95-016. USA

US EPA (2000) Biosolids technology fact sheet alkaline stabilization of biosolids. Office of Water Washington, DC Environ. Prot. Age. 832-F-00-052

US EPA (2004a) Primer for municipal wastewater treatment systems. US environmental protection agency municipal support, division office of wastewater management office of water Washington, DC, EPA 832-R-04-001

US EPA (2004b) Guidelines for Water Reuse, US Environmental Protection agency municipal support, division office of wastewater management office of water Washington, DC, September 2004

US EPA (2007) Pathogens, pathogen indicators and indicators of fecal contamination. Airlie Center, Warrenton, Virginiam US environmental protection agency, office of water, office of research and development. EPA 823-R-07-006

US EPA (2009) Terms of environment: glossary, abbreviations, and acronyms. Office of the Administrator/Office of External Affairs and Environmental Education

US EPA (1989) Hazardous waste treatment, storage, and disposal facilities (TSDF), Air Emission Models, EPA-450/3-87-026. Environmental Protection Agency, Research Triangle Park, Washington

US EPA (1994) Standards for the use or disposal of sewage sludge. Environmental protection agency; 40 CFR Part 503. Fed Regist 58:9248-9415

US EPA (2003) Control of pathogens and vector attraction in sewage sludge; 40 CFR Part 503. Environmental Protection Agency, Cincinnate, p 45268

van Frankenhuyzen JK, Trevors JT, Lee H, Flemming CA, Habash MB (2011) Molecular pathogen detection in biosolids with a focus on quantitative PCR using propidium monoazide for viable cell enumeration. J Microbiol Methods 87(3):263-272

Veenstra G, Alaerts J, Bijlsma M (1997) Technology selection, chapter 7. In: Helmer R, Hespanhol I (Eds.) Water pollution controla guide to the use of water quality management principles. Published on behalf of the United Nations Environment Programme, the Water Supply and Sanitation Collaborative Council and the World Health Organization by E. and F. Spon. 1997 WHO/ UNEP. ISBN, 0419229108

Velickovic-Radovanovic R, Petrovic J, Kocic B (2009) Correlation between antibiotic consumption and bacterial resistance as quality indicator of proper use of these drugs in inpatients. Vojnosanit Pregl 66(4):307-312

Viau E, Peccia J (2009) Survey of wastewater indicators and human pathogen genomes in biosolids produced by class $a$ and class $b$ stabilization treatments. Appl Environ Microbiol 75(1):164-174

Vierheilig J, Frick C, Mayer RE, Kirschner AKT, Reischer GH, Derx J, Mach RL, Sommer R, Farnleitner AH (2013) Clostridium perfringens is not suitable for the indication of faecal pollution from ruminant wildlife but is associated with excreta from nonherbivorous animals and human sewage. Appl Environ Microbiol 79(16):5089-5092

Vila J, Gascon J, Abdalla S, Gomez J, Marco F, Moreno A, Corachan M, Jimenez T (1994) Antimicrobial resistance of Shigella isolates causing traveler's diarrhea. Antimicrob Agents Chemother 38(11):2668-2670
Vilanova X, Blanch AR (2005) Distribution and persistence of faecal bacterial populations in liquid and dewatered sludge from a biological treatment plant. J Gen Appl Microbiol 51(6):361-368

Vital M, Stucki D, Egli T, Hammes F (2010) Evaluating the growth potential of pathogenic bacteria in water. Appl Environ Microbiol 67(19):6477-6484

Wakelin S, Racz G, Oleszkiewicz J, Szoke N, Barsalou P (2003) Estimating the potential for disease in nearby residents as a result of the city of Winnipeg biosolids land application program (Win GRO). In: Presented at 2nd ed. Organic Residuals Recycling Conference, April 2003

Wang X, Hu X, Wang H, Hu C (2012) Synergistic effect of the sequential use of UV irradiation and chlorine to disinfect reclaimed water. Water Res 46(4):1225-1232

Wani D, Pandit AK, Kamili ZN (2013) Microbial assessment and effect of seasonal change on the removal efficiency of FAB based sewage treatment plant. J Environ Eng Ecol Sci 2:1-3

Ward RL, Yeager JG, Ashley CS (1981) Response of bacteria in wastewater sludge to moisture loss by evaporation and effect of moisture content on bacterial inactivation by ionizing radiation. Appl Environ Microbiol 41(5):1123-1127

WEF (1995) Wastewater residues stabilization. Manual of Practice FD-9. Water Environment Federation, USA

Wen Q, Tutuka C, Keegan A, Jin B (2009) Fate of pathogenic microorganisms and indicators in secondary activated sludge wastewater treatment plants. J Environ Manag 90(3):1442-1447

WHO (1989) Health guidelines for the use of wastewater in agriculture and aquaculture. Technical Report Series 778, World Health Organization, Geneva. Switzerland

WHO (1993) Guidelines for drinking-water quality. Recommendations, 2nd edn. WHO, Geneva. ISBN 9241544600

WHO (2001) Water quality. In: Fewtrell L, Bartram J (eds). Guidelines, standards and health: assessment of risk and risk management for water-related infectious disease. IWA, London. (ISBN)

WHO (2002) Environmental health regional office for the Eastern Mediterranean (EMRO). Regional Centre for Environmental Health Activities CEHA, Amman

Wilén BM, Johanssen A, Mattsson A (2012) Assessment of sludge particle removal from wastewater by disc filtration. Chalmers University of Technology and Gryaab, Göteborg, Water Practice Technol. https://doi.org/10.2166/wpt.2012.037

Wong K, Onan BM, Xagoraraki I (2010) Quantification of enteric viruses, pathogen indicators, and salmonella bacteria in class b anaerobically digested biosolids by culture and molecular methods. Appl Environ Microbiol 76(196):441-6448

Woteki CE, Kineman BD (2003) Challenges and approaches to reducing foodborne less. Ann Rev Nut 23:315-344

Xu P, Savoye P, Cockx A, Lazarova V (2002) Wastewater disinfection by ozone: main parameters for process design. Water Res 36(4):1043-1055

Yachigo M, Sato S (2013) Leachability and vegetable absorption of heavy metals from sewage sludge biochar (Chapter 15). In: Maria C. Hernandez Soriano (Ed.) Soil processes and current trends in quality assessment. (ISBN 978-953-51-1029-3, CC BY 3.0 license)

Ye L, Zhang T (2011) Pathogenic bacteria in sewage treatment plants as revealed by 454 pyrosequencing. Environ Sci Technol 45(17):7173-7179

Young KD, Thackston EL (1999) Housing density and bacterial loading in urban streams. J Environ Eng 125(12):1177-1180

Younis M, Soleiman HA, Abou-Elmagd K (2003) Microbiological and chemical evaluation of bentonite as a new technique for sewage water treatment, Aswan city, Egypt. In: 7th International Water Technology Conference Egypt 1-3 April 2003: 323-343

Yurtsever D (2005) Use of treatment plant sludges as biosolids. M. Sc. Thesis, Dokuz Eylul University. IZMIR 
Zhou H, Smith DW (2002) Advanced technologies in water and wastewater treatment. J Environ Eng Sci 1:247-264

Ziemba C, Peccia J (2011) Net energy production associated with pathogen inactivation during mesophilic and thermophilic anaerobic digestion of sewage sludge. Water Res 45(16):4758-4768 